\title{
Flavonoids and Stilbenoids of the Genera Dracaena and Sansevieria: Structures and Bioactivities
}

\author{
Zaw Min Thu ${ }^{1, *(\mathbb{D})}$, Ko Ko Myo ${ }^{1}$, Hnin Thanda Aung ${ }^{2}$, Chabaco Armijos ${ }^{3, *(\mathbb{D})}$ and \\ Giovanni Vidari ${ }^{4, *}$ \\ 1 Department of Chemistry, Kalay University, Kalay 03044, Sagaing Region, Myanmar; \\ kokomyokalay@gmail.com \\ 2 Department of Chemistry, University of Mandalay, Mandalay 100103, Myanmar; \\ hninthandaaung07@gmail.com \\ 3 Departamento de Química y Ciencias Exactas, Universidad Técnica Particular de Loja, \\ San Cayetano Alto s/n, Loja 1101608, Ecuador \\ 4 Medical Analysis Department, Faculty of Science, Tishk International University, Erbil 44001, Iraq \\ * Correspondence: zawminthu87@gmail.com (Z.M.T.); cparmijos@utpl.edu.ec (C.A.); vidari@unipv.it (G.V.)
}

Received: 18 May 2020; Accepted: 2 June 2020; Published: 3 June 2020

\begin{abstract}
The genera Dracaena and Sansevieria (Asparagaceae, Nolinoideae) are still poorly resolved phylogenetically. Plants of these genera are commonly distributed in Africa, China, Southeast Asia, and America. Most of them are cultivated for ornamental and medicinal purposes and are used in various traditional medicines due to the wide range of ethnopharmacological properties. Extensive in vivo and in vitro tests have been carried out to prove the ethnopharmacological claims and other bioactivities. These investigations have been accompanied by the isolation and identification of hundreds of phytochemical constituents. The most characteristic metabolites are steroids, flavonoids, stilbenes, and saponins; many of them exhibit potent analgesic, anti-inflammatory, antimicrobial, antioxidant, antiproliferative, and cytotoxic activities. This review highlights the structures and bioactivities of flavonoids and stilbenoids isolated from Dracaena and Sansevieria.
\end{abstract}

Keywords: Dracaena; Sansevieria; biological/pharmacological activities; flavonoids; stilbenoids

\section{Introduction}

The taxonomic boundaries of the dracaenoid genera Dracaena and Sansevieria have long been debated. In the APG IV system of flowering plant classification, the two genera are still differentiated; both have been placed in the subfamily Nolinoideae of the family Asparagaceae, in the order Asparagales [1]. However, recent molecular phylogenetic studies showed that Sansevieria was nested within Dracaena, rendering the latter paraphyletic unless Dracaena was expanded to include species formerly placed in Sansevieria [2-4]. In this paper we have maintained the historical division in the two genera because the chemical literature is mainly based on the former botanical classification. However, known Dracaena synonyms for Sansevieria species are also reported.

The genus Dracaena consists of more than 100 accepted species which are mainly distributed in the tropics and subtropics, especially in Africa, Australia, and Southern Asia [5]. They are mainly succulent shrubs and trees, and a few are commonly grown as shrubby houseplants, especially the variegated forms. The complete chloroplast (CP) genomes of six species have recently been reported, showing that can be used as a super-barcode for Dracaena spp. identification [6].

"Dragon's blood" is a non-specific name for deep red resinous exudates that are obtained from cut stems of different plant taxa endemic to various regions around the globe and belonging to the families of Asparagaceae, Arecaceae, Chamaesyce (Euphorbiaceae), and Fabaceae [7,8]. About six Dracaena plants, 
growing in China, Southeast Asia, West Africa, Arabian Peninsula, Yemen, India, and Macaronesia are the main sources of this resin [6,8]. The drug (Figure 1a) was a commercially important export, notably from the island of Socotra (Yemen) (Figure 1b) and it has widely been used in traditional medicines through the world for thousands of years as an efficacious remedy for the treatment of hemorrhage, dysentery, diarrhea, stomach and external ulcers, wounds, leucorrhea, fractures, piles, diabetes, and even tumors [6,8-11]. In fact, the resin is known to have remarkable anti-inflammatory and antioxidant effects and to enhance immune function, promote skin repair, stop bleeding, and enhance blood circulation [8-10,12,13]. Dragon's blood is included in the Pharmacopoeia of the People's Republic of China, where it was first imported through the silk road during the Sui and Tang dynasties. Until the 1970s, the red resin of Dracaena cochinchinensis S. C. Chen, used originally by the Dai people, living in the south part of Chinese Yunnan province, for treating pain and stopping hemorrhages, was found and used as the substitute of the traditionally imported dragon's blood, called Long-Xue-Jie (Chinese dragon's blood) [9,10].

Besides medicinal uses, the resin has also been employed as a pigment in works of art since ancient times by many cultures. In addition to flavonoids and stilbenoids (vide infra), chemical and pharmacological studies have indicated that other phenolic compounds, saponins, and terpenes are the main effective compounds occurring in dragon's blood [8-11].

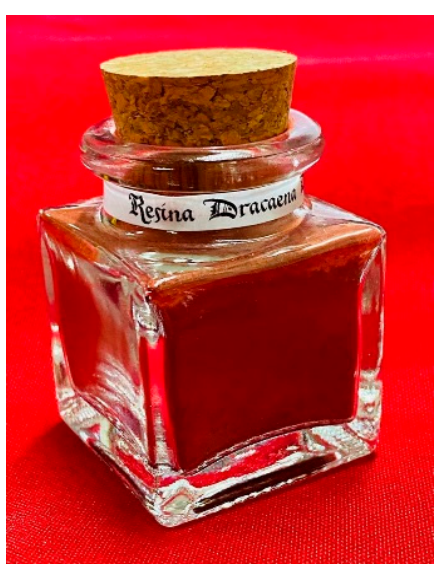

(a)

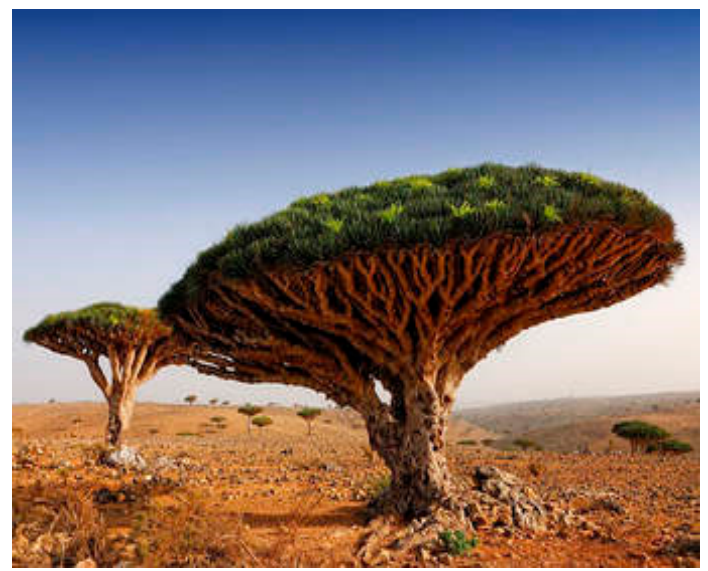

(b)

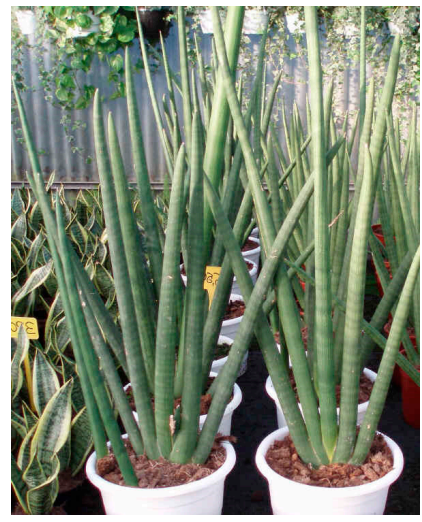

(c)

Figure 1. (a) Dragon's blood; (b) Dracaena cinnabari Balf. f. (Socotra, Yemen); and (c) Sansevieria cylindrica Bojer ex Hook. The images have been downloaded from the Internet.

The genus Sansevieria includes species (Figure 1c) with a distribution ranging from Africa, Madagascar through Asia to Myanmar and the islands of the Indian Ocean [14,15]. The genus comprises perennial herbs with erect, stiff leaves and short, thick, and stoloniferous rhizomes. Common names for the about 70 or more known species include mother-in-law's tongue, devil's tongue, cow tongue, 
bow-string hemp, snake plant, and zebra lily [14,15]. The genus was originally named Sanseverinia by Vincenzo Petagna in 1787, to honor his patron Pietro Antonio Sanseverino, Count of Chiaromonte (1724-1771), in whose garden Petagna saw the plant. In 1794 Thunberg used the name Sansevieria that, since that time, has been conserved in the botanical literature [16]. The name honors Italian scientist and inventor Raimondo di Sangro (1710-1771), Prince of Sanseviero. The spellings "Sanseveria" and "Sanseviera" are commonly used as well, the confusion deriving from alternate spellings of the Italian place name. The leaves and rhizomes of Sansevieria genus are used in folk medicine for treating asthma, cough, sexual weakness, hypertension, abdominal pains, colic, eczema, piles, edema, jaundice, anuria, palpitations, viral hepatitis, malaria, snake- and insect bites, etc. [15,17-20].

Besides the medicinal aspects, several Dracaena and Sansevieria species have great horticultural importance and are commercialized for use in landscaping and as indoor ornamental plants [21]. Moreover, it has been reported that Dracaena spp. can be used as bioindicators for the control of increasing air pollution in urban cities [22].

This review describes the most characteristic flavonoids and stilbenes isolated from Dracaena and Sansevieria species that have been investigated so far; the main biological activities are also reported. Compounds found in each species have been divided according to the plant organ from which they have been isolated. The literature has been retrieved from the databases Reaxys and Google Scholar until February 2020. A few papers written in Chinese (see reference [8]) could not be reviewed.

\section{Bioactive Flavonoids and Stilbenoids from the Genera Dracaena and Sansevieria}

\subsection{Dracaena Species}

\subsubsection{Dracaena angustifolia Medik, (Roxb.)}

The native range of this shrub is from Bangladesh, through Indochina and Malaysia to Northern Australia. Tazettone $\mathrm{H}$ (structure 1 in Figure 2), (2R)-7,3'-dihydroxy-5',5-dimethoxy-8-methylflavan (2), (2R)-7,4'-dihydroxy-5,3'-dimethoxy-8-methylflavone, (2R)-7,4'-dihydroxy-5-methoxy-8-methylflavanone, 5,4'-dihydroxy-7-methoxy-8-methylflavan, 4'-hydroxy-5,7-dimethoxy-8-methylflavan, (3S)-3,5,7-trihydroxy$4^{\prime}$-methoxyhomoisoflavanone, 5,7,4'-trihydroxy-6-methyl-homoisoflavanone, desmethylisoophiopogonone B (3), and 5,7,4'-trihydroxyhomoisoflavone (4) were isolated from the stems [23].
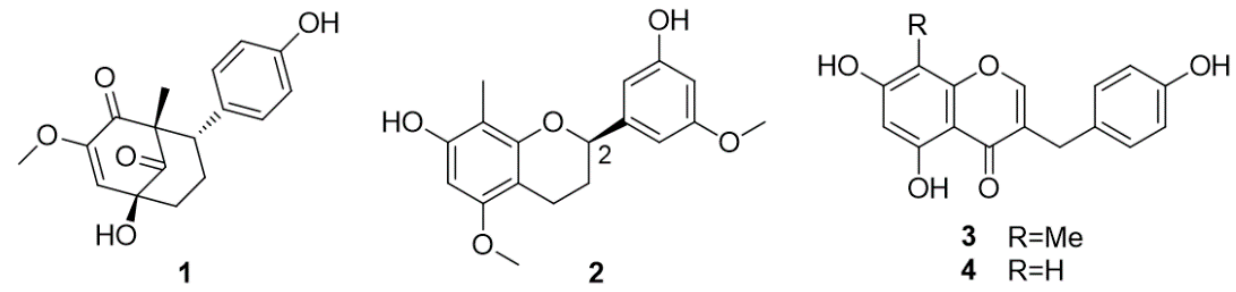

Figure 2. Chemical structures of compounds 1-4 isolated from D. angustifolia.

Compounds 2-4 displayed weak anti-inflammatory activity with $\mathrm{IC}_{50}$ values of 45,33 and $61 \mu \mathrm{M}$, respectively [23].

\subsubsection{Dracaena cambodiana Pierre ex Gagnep}

The plant grows in China and Southeast Asia. Intense investigations of dragon's blood led to the isolation of cambodianins A (5) and B (6), 4,4'-dihydroxy-2,3'-dimethoxydihydrochalcone (7), 4,4'-dihydroxy2-methoxydihydrochalcone (loureirin C) (8), 4,4'-dihydroxy-2,6-dimethoxy-dihydrochalcone, 4,2', $4^{\prime}$-trihydroxychalcone (10), 4,4'-dihydroxy-2'-methoxychalcone (11), (2S)-7,3' -dihydroxy-4'-methoxy8-methylflavan (9), (2S)-7,4'-dihydroxyflavanone (12), (3R)-7,4'-dihydroxyhomoisoflavanone (13) (Figure 3), together with cambodianins D (14) and E (15), (2S)-7,4'-dihydroxy-6,8-dimethylflavan (16), cambodianins G (18) and H (19) (Figure 4) [24-26]. 
In an MTT assay, 4,4'-dihydroxy-2,6-dimethoxydihydrochalcone and compounds 5, 6, 11, and 13 exhibited moderate cytotoxic effects against human myelogenous leukemia (K-562), human hepatocarcinoma (SMMC-7721), and human gastric tumor (SGC-7901) cell lines [24]. Compound 18 was moderately cytotoxic against K562 and SGC-7901 cell lines with IC 50 values of 9.5 and $16.2 \mu \mathrm{g} / \mathrm{mL}$, respectively [26]. Compounds 5-16, 18, and 19 showed antibacterial activities against Staphylococcus aureus and compounds 5, 6, 7, 8, 10, 12, and 13-16 also exhibited antibacterial effects against methicillin-resistant $S$. aureus (MRSA) [24-26]. The dragon's blood of D. cambodiana also produced 5,7-dihydroxy-4' -methoxy-8-methylflavan, 7,4'-dihydroxy-8-methoxyhomoisoflavan, (2R)-7,4'-dihydroxy8-methylflavan, and (2S)-7,3'-dihydroxy-4'-methoxyflavan [27]. The Dai and Mei research group isolated the biflavonoids 8-methyl-3'-methoxysocotrin- $4^{\prime}$-ol (cochinchinenin D) (structure 17 in Figure 4), 8-methyl-4'-methoxysocotrin-3'-ol, and 8-methylsocotrin- $4^{\prime}$-ol, together with (2S)-7, $4^{\prime}$-dihydroxy6,8-dimethylflavan, (2S)-5,7-dihydroxy-4'-methoxy-8-methylflavan, (2S)-7,3'-dihydroxy-4' -methoxy-8methylflavan (9), (2R)-7,4' -dihydroxy-8-methylflavan, ( \pm )-7, $3^{\prime}$-dihydroxy-4' -methoxyflavan, $( \pm)-7,4^{\prime}-$ dihydroxy-3'-methoxyflavan, and (2S)-7, $4^{\prime}$-dihydroxyflavan from the stems of $D$. cambodiana [28-30]. The antimicrobial activities of these compounds were reported. In addition, a new homoisoflavonoid, named cambodianol (structure 20 in Figure 5), was isolated from the same sample.

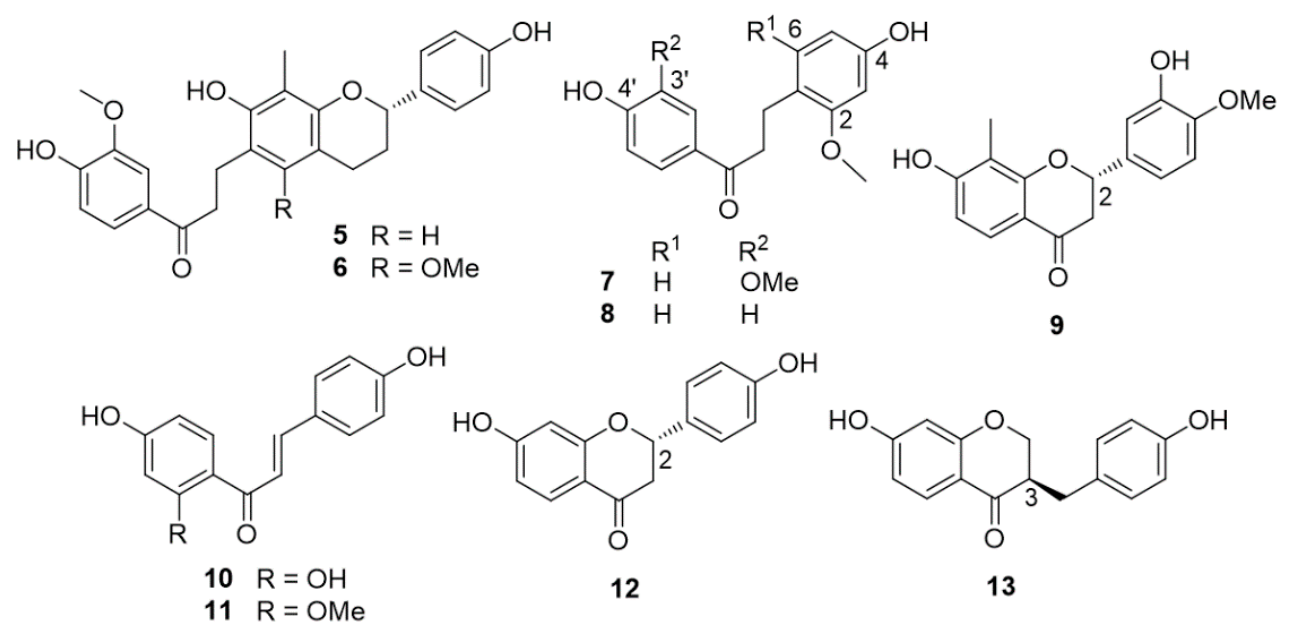

Figure 3. Chemical structures of compounds 5-13 isolated from D. cambodiana.

Cambodianol exhibited high cytotoxic activity against chronic myelogenous leukemia (K562), human hepatoma (SMMC-7721), and human gastric cancer (SGC-7901) cells in an MTT assay with IC $_{50}$ values of $1.4,2.9$, and $5.0 \mu \mathrm{g} / \mathrm{mL}$, respectively, that were comparable with those of paclitaxel [30,31]. 7,4'-Dihydroxy-8-methoxyhomoisoflavan, 7,4'-dihydroxyhomoisoflavan, 4,4' -dihydroxy-2-methoxy dihydrochalcone, 4,4' -dihydroxy-3,2' -dimethoxychalcone, 4,2' , $4^{\prime}$-trihydroxychalcone, 4,4' -dihydroxy$2^{\prime}$-methoxychalcone were also isolated from D. cambodiana stems [32,33]. 4,4'-Dihydroxy-3,2'-dimethoxy chalcone showed significant activity against chronic myelogenous leukemia (K562), human hepatoma (SMMC-7721), and human gastric cancer (SGC-7901) cells in an MTT assay, with $\mathrm{IC}_{50}$ values of 2.5, 4.3, and $4.4 \mathrm{mg} / \mathrm{mL}$, respectively. These values were comparable with those of mitomycin C [32]. The antioxidant and radical scavenging activities of compounds 20, (2S)-7,3' -dihydroxy-4'-methoxy-8-methylflavan (9), (2R)-7, $4^{\prime}$-dihydroxy-8-methyl flavan, ( \pm -)-7,4' -dihydroxy-3' -methoxyflavan, (2S)-7, $4^{\prime}$-dihydroxyflavan, $7,4^{\prime}$-dihydroxyhomoisoflavan, and 4,4'-dihydroxy-2'-methoxychalcone were from weak to moderate [33]. 


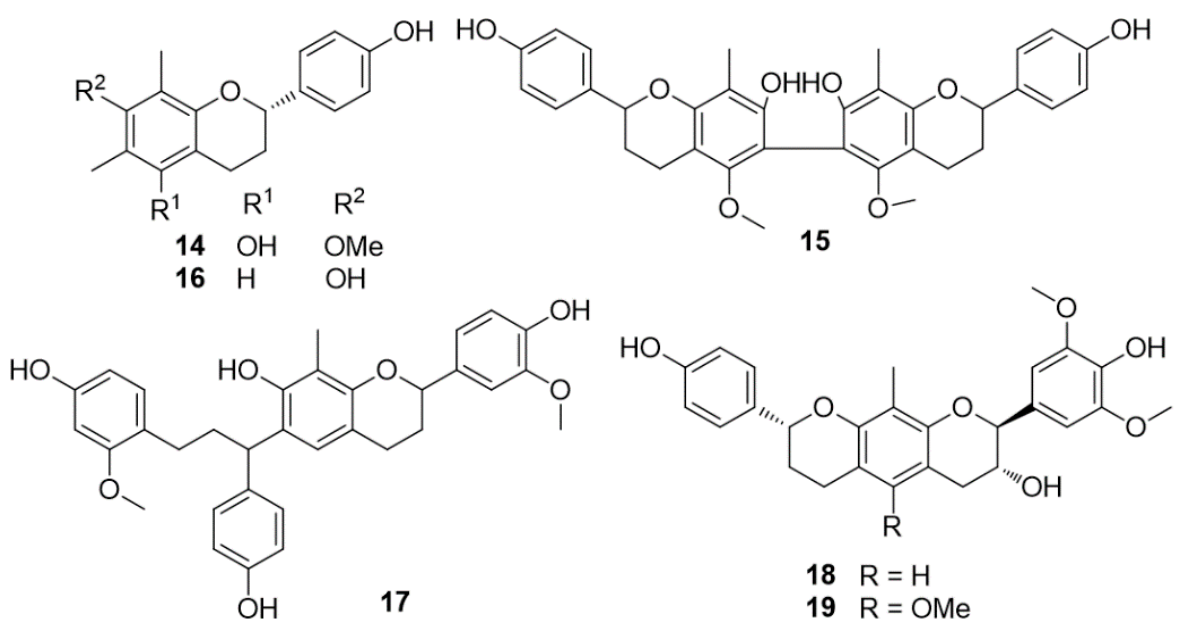

Figure 4. Chemical structures of compounds 14-19 isolated from D. cambodiana.

Dragon's blood of $D$. cambodiana, artificially induced by mineral salt and acid injection into trunk of the plant by transfusion $[31,34]$, produced a wide range of phenolic compounds, some of which were the same as those isolated from the natural red resin. They include (2R)-7,4'-dihydroxy-8-methylflavan, (2R)-7, $4^{\prime}$-dihydroxy-6-methylflavan (21), (2S)-7, $4^{\prime}$-dihydroxyflavan, (2S)-5,4'-dihydroxy-7-methoxy6,8-dimethylflavan, (2S)-7, $3^{\prime}, 4^{\prime}$-trihydroxy-8-methylflavan, (2S)-7, $4^{\prime}$-dihydroxy-3'-methoxyflavan, ( \pm )-7, $4^{\prime}$-dihydroxy-3'-methoxyflavan, (2S)-5,7-dihydroxy-4'-methoxy-8-methylflavan, (2S)-7,3'-dihydroxy$4^{\prime}$-methoxy-8-methylflavan, (3R)-7, $4^{\prime}$-dihydroxyhomoisoflavan, (3R)-7, $4^{\prime}$-dihydroxy-8-methoxyhomois oflavan, (3R)-7, 3' , $4^{\prime}$-trihydroxyhomoisoflavan (22) (Figure 5), 2,4,4' -trihydroxy-3' -methoxy-3-methydih ydrochalcone, 2,4,4' -trihydroxy-3-methydihydrochalcone, 4,2', $4^{\prime}$-trihydroxy-3-methoxychalcone, $( \pm)-5$, 7,4'-trihydroxy-6-methylhomoisoflavanone, ( \pm )-7, $4^{\prime}$-dihydroxyhomoisoflavanone, (3S)-7,3' -dihydroxy4'-methoxyhomoisoflavanone, (3R)-cambodianol (20), (2S)-7,4'-dihydroxyflavanone, pterostilbene, 10-hydroxy-11-methoxydracaenone C, 10,11-dihydroxydracaenone C, (3E)-7-hydroxy-3-[(3-hydroxy4-methoxybenzylidene)chroman-4-one, (3E)-7-hydroxy-3-(4-hydroxybenzylidene)chroman-4-one, 3'methoxy-8-methylsocotrin-4'-ol, 4' -methoxy-8-methylsocotrin-3'-ol, and 8-methylsocotrin-4'-ol [31,34]. $( \pm)-7,4^{\prime}$-Dihydroxyhomo-isoflavanone and 8-methylsocotrin-4'-ol exhibited moderate cytotoxic effects against human myeloid leukemia (K562) and human gastric tumor (SGC-7901) cell lines $\left(\mathrm{IC}_{50}=16-29 \mu \mathrm{g} / \mathrm{mL}\right)$ [30], whereas compound 21 was weakly cytotoxic against human hepatoma (BEL-7402) cells $\left(\mathrm{IC}_{50}=39.2 \mu \mathrm{M}\right)$ [34]. Compound 22 showed significant acetylcholinesterase (AChE) inhibitory activity [34]. Most isolated compounds demonstrated antibacterial activity against S. aureus; instead, they were only weakly active against MRSA [31].<smiles>COc1ccc(C2(O)COc3cc(O)c(C)c(O)c3C2=O)cc1</smiles>

20<smiles>Cc1cc2c(cc1O)OC(c1ccc(O)cc1)CC2</smiles>

21<smiles>Oc1ccc2c(c1)OCC(Cc1ccc(O)c(O)c1)C2</smiles>

22

Figure 5. Chemical structures of compounds 20-22 isolated from D. cambodiana.

\subsubsection{Dracaena cinnabari Balf. f.}

The plant grows in Arabian Peninsula and Yemen, especially in the island of Socotra (Figure 1b) where it has become a touristic attraction. From the red resin of the plant collected at Socotra, known in Arabic as Dammalakhawin or Cinnabar, Masaoud et al. isolated 7, $3^{\prime}$-dihydroxy-4'-methoxyhomo isoflavan, 7,4'-dihydroxy-8-methoxyhomoisoflavan, $4^{\prime}$-hydroxy-7,8-methylendioxy-homoisoflavan (structure 23 in Figure 6), 7,4'-dihydroxyhomoisoflavan, ( \pm )-7, $4^{\prime}$-dihydroxy-3'-methoxyflavan, (2S)-7, $3^{\prime}$-dihydroxy-4'-methoxyflavan, (2S)-7-hydroxyflavan, 4,4'-dihydroxy-2' -methoxychalcone, 4-hydroxy- 
2-methoxydihydrochalcone, 4,4'-dihydroxy-2-methoxydihydro- chalcone, (2S)-7-hydroxyflavanone, and 7,4'-dihydroxyflavone [35].<smiles>[Z20]Oc1cc(O)c(Cc2c(O)ccc(C(=O)/C=C/c3ccccc3)c2O)cc1CCC(=O)c1ccccc1</smiles>

Figure 6. Chemical structures of compounds 23-25 isolated from D. cinnabari.

Compound 23 inhibited nitric oxide (NO), TNF- $\alpha$, and IL-6 production in lipopolysaccharidestimulated mouse macrophage RAW 264.7 cells [36], thus having potential anti-inflammatory activity.

Unprecedented phenols isolated from the resin were the C-linked chalcone-dihydrochalcone dimer dracidione (structure 24 in Figure 6) [37], the triflavonoid damalachawin (structure 25 in Figure 6) [38], the biflavonoids cinnabarone (26) [39], 2'-methoxysocotrin-5'-ol (27), socotrin-4' -ol (28), and homoisosocotrin-4'-ol (29) [40], and the metacyclophane dracophane (structure 30 in Figure 7) [41]. Dracidione (24) showed moderate $\alpha$-glucosidase inhibitory activity ( $\mathrm{IC}_{50}=40.27 \mu \mathrm{g} / \mathrm{mL}$ ) [37].

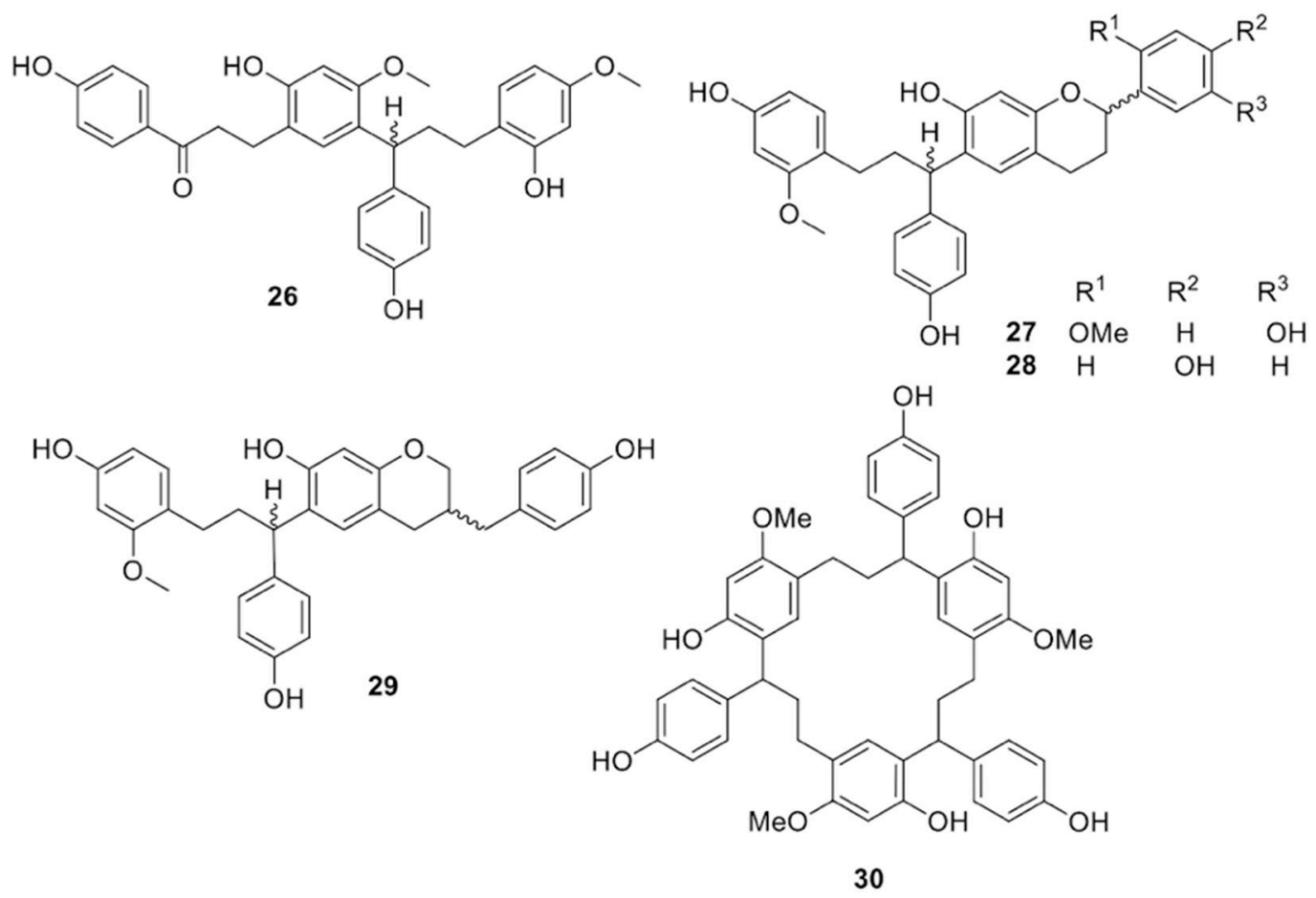

Figure 7. Chemical structures of compounds $\mathbf{2 6 - 3 0}$ isolated from D. cinnabari.

\subsubsection{Dracaena cochinchinensis (Lour.) S.C. Chen}

The plant grows in China and Southeast Asia. Phytochemical and pharmacological investigations performed on $D$. cochinchinensis extracts are innumerable, given the wide use of the drug in the traditional Chinese medicine. Several extracts of the plant, especially of the red resin, known as 
Chinese dragon's blood or Yunnan dragon's blood, have been true mines of a great number of novel compounds with intriguing structures (Figures 8-16). The immunomodulatory, antibacterial, antiviral, antidiarrheal, antioxidant, antiatherosclerosis, antiulcer, antiseptic, mutagenic and antimutagenic, antitumor, anticancer, and cytotoxic effects of Chinese dragon's blood have been proved by pharmacological investigations [42]. The drug is commonly prescribed to improve blood circulation, to stop hemorrhages, and to heal wound cuts and pains [42]. It has also been used to treat a diverse range of peripheral inflammation and central inflammation-associated diseases such as diabetes, arthritis, colitis, gynecopathy, and allergic dermatitis [42]. A Chinese pharmaceutical formulation, named Longxuetongluo Capsule (LTC), which is derived from the total phenolic extract of Chinese dragon's blood, has been proved to be safe as well as effective against ischemic stroke. At least ten different research groups, mainly from China, have isolated and determined the structures of a great number of flavonoids and stilbenoids from the red resin. To avoid repetitions, compounds have been grouped according to their biosynthetic families. Flavones (Figure 8): 7-hydroxy-6-methoxyflavone [43], 7,3'-dihydroxy-4'-methoxyflavone (31) [44], 7,4'-dihydroxyflavone (32) [44-46], 7-hydroxyflavone (33) [42], 5,7,4'-trihydroxy-8-methylflavone [42], 5,7,4'-trihydroxyflavone (apigenin) [42]. Flavanones: 7,4'-dihydroxyflavanone (liquiritigenin) [42,44], (2S)-5,7-dihydroxyflavanone (pinocembrin) [42]. Chalcones: 4,4'-dihydroxy-2-methoxychalcone (echinatin) [42,46], 4,4'-dihydroxy-3' -methoxychalcone [44], 4,4'-dihydroxy-2'-methoxychalcone (11) [44,47]. Dihydrochalcones derivatives (Figure 8): 6-methoxy-3methyl-(1-hydroxy-3-(4-hydroxyphenyl)propyl)-bicyclo[3.1.0]hex-6-ene-2,4-dione ("cochinchinenene $\left.\mathrm{H}^{\prime \prime}\right)$ (34) [42], 4-hydroxy-2,4' -dimethoxy-dihydrochalcone [48], 3,4'-dihydroxy-2,4,6-trimethoxydihydrochal cone [48], 2,4,4'-trihydroxy- dihydrochalcone [47,48], cochinchinenone (35) [47], 4'-hydroxy-2,4-dimeth oxydihydrochalcone (loureirin A) (36) [43,45-48], 4'-hydroxy-2,4,6-trimethoxydihydrochalcone (loureirin B) $[43,45,46,48]$, 2,4'-dihydroxy-4,6-dimethoxydihydrochalcone (37) [48], loureirin C (8) [42,44,46-48],4,4'-dihydroxy-2,6-dimethoxydihydrochalcone [42,44,46,47,49], 4,6,4' -trihydroxy-2methoxydihydrochalcone [47], 4' -hydroxy-4,2'-dimethoxydihydrochalcone (38) [50], and 4-hydroxy-2', 6'-dimethoxydihydro-chalcone (39) [51].
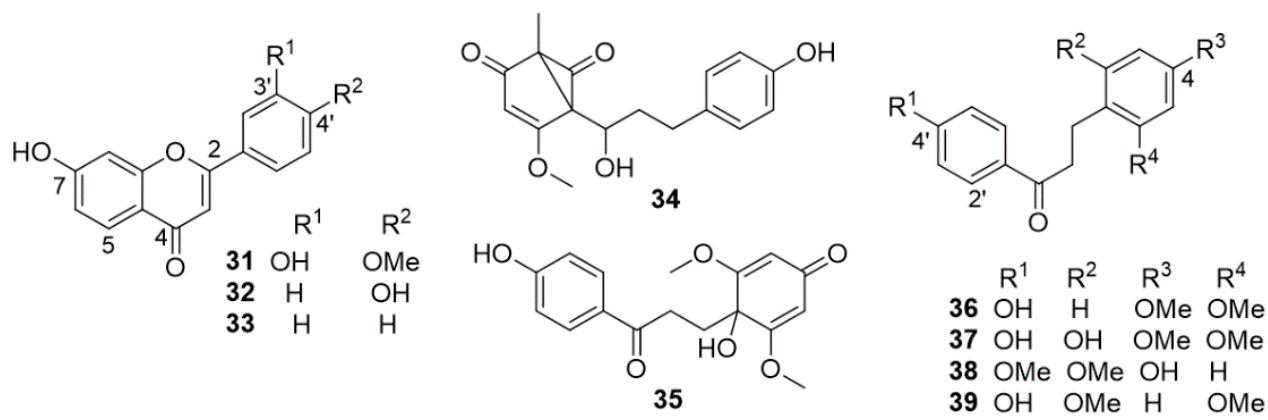

Figure 8. Selected flavones and dihydrochalcone derivatives from $D$. cochinchinensis red resin.

Homoisoflavones: 5,4'-dihydroxy-7-methoxyhomoisoflavone [52], 7,4'-dihydroxyhomoisoflav one [46], 7-hydroxy-3-(4-hydroxy-benzylidene)chroman-4-one [42]. Homoisoflavanones (Figure 9): (3S)-3,7-dihydroxy-4'-methoxyhomoisoflavanone [(3S)-dracaeconolide A] (40) [49], (3S)-3,7,4' -trihydroxy5-methoxyhomoisoflavanone (41), (3S)-7,4'-dihydroxy-5-methoxyhomoisoflavanone [42,52], 7,4' dihydroxyhomoisoflavanone (42) [42,43,52], (3S)-7,4'-dihydroxyhomoiso flavanone [44], 3,5,7,4' -tetra hydroxyhomoisoflavanone (loureiriol) [52], and 7,4'-dihydroxy-8-methoxyhomoisoflavanone [47]. Stilbenoids (Figure 9): trans-resveratrol [42,44], 3,4'-dihydroxy-5-methoxystilbene [42], cis-resveratrol [42], trans-3,5-dihydroxy-4' -methoxystilbene [47], trans-3,5,4'-trihydroxystilbene [47], pterostilbene (4'-hydroxy3,5-dimethoxystilbene) (43) [43], 3-methylresveratrol [44], and cochinchin (structure 44 in Figure 9) [45]. 

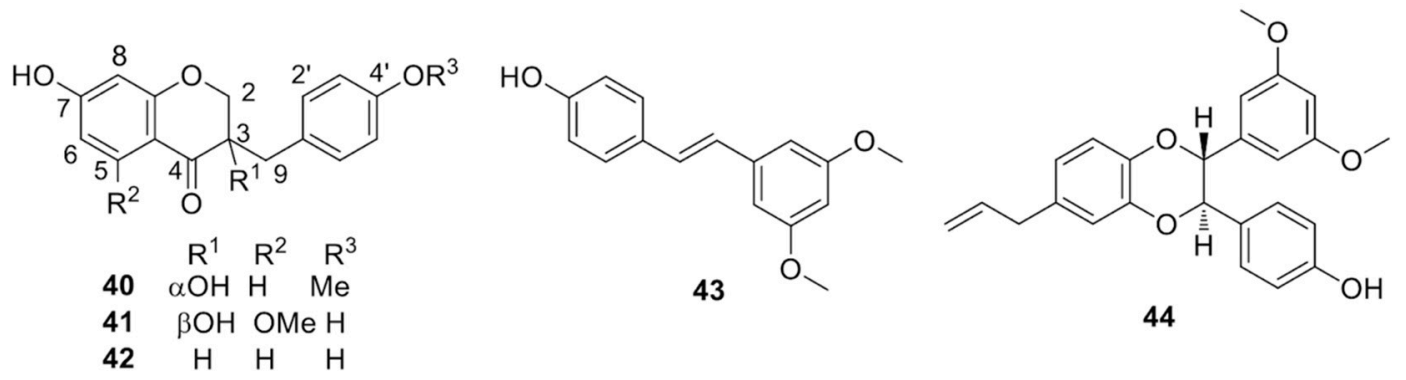

Figure 9. Selected homoisoflavanones and stilbenoids from D. cochinchinensis red resin.

Flavans (Figure 10): 7,4'-dihydroxy-8-methylflavan (45) [43,44,49], 4,4'-dihydroxy-2,6-dimethoxy dihydrochalcone [47,48], (2R)-7,4' -dihydroxy-5-methoxy-8-methylflavan [49], 5,4'-dihydroxy-7-methoxy6-methylflavan (46) [44,46,49], 7,4'-dihydroxy-3'-methoxyflavan [49], 7,4'-dihydroxyflavan (47) [46,49], (-)-7-hydroxy-4'-methoxyflavan [43,45-47], (2S)-7,4'-dihydroxy-8-methylflavan (48) [46,47], (2S)-5, $4^{\prime}$-dihydroxy-7-methoxy-8-methylflavan [47], (2R)-4'-hydroxy-7-methoxy-8-methylflavan [47], and 6,4'dihydroxy-7-methoxy-8-methylflavan [46].

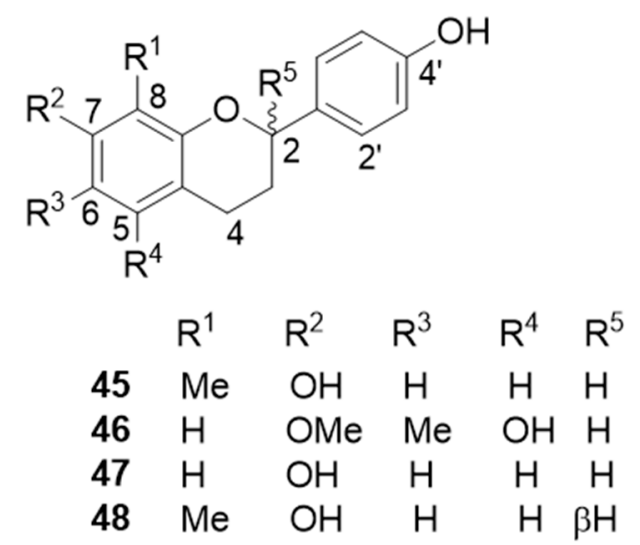

Figure 10. Selected flavans from D. cochinchinensis red resin.

Homoisoflavans and meta-homoisoflavans (Figure 11): (3R)-7,4'-dihydroxy-5,8-dimethoxy-homo isoflavan [(3R)-dracaeconolide B] (49) [49] (Figure 11) (3R)-7, 4'-dihydroxy-8-methoxy-homoisoflavan (50) $[48,49,53],(3 R)-7,4^{\prime}$-dihydroxyhomoisoflavan (51) [45,46,48,49], (3R)-7, $4^{\prime}$-dihydroxy-5-methoxy homoisoflavan (52) [42,46,48,49], 7,4'-dihydroxyhomoisoflavan (53) [43,44], (3R)-7,4'-dihydroxy-6methoxyhomoisoflavan [52], 6, ' '-dihydroxy-7-methoxyhomoisoflavan (54) [43,46], (3R)-6,4' -dihydroxy8-methoxyhomoisoflavan [49], 7,3'-dihydroxy-8,4'-dimethoxyhomo- isoflavan [48], 4'-hydroxy-7,8dimethoxyhomoisoflavan [48], 4'-hydroxy-5,7-dimethoxyhomo- isoflavan [48], (7R,12bR)-7,10-dihydroxy4,11-dimethoxydracaenone (55) [52], (7S,12bS)-11-hydroxy-1,10-dimethoxydracaenone (56) [52], (7S, 12bS)-10,11-dihydroxy-1-methoxydracaenone (57) [52], 10-hydroxy-11-methoxydracaenone (58) [52], 10,11-dihydroxydracaenone C (59) [44], and 4'-hydroxy-7,8-methylenedioxyhomoisoflavan (23) [46,48].

Flavonoid dimers and trimers (Figures 12 and 13): cochinchinenenes A-D (structures 60,63-65 in Figure 11) [44,47,53], cochinchinenenes E (66) and F (61) [43], cochinchinenenes $G(67)$ and $\mathrm{H}$ (62) [44], "cochinchinenene G" (68) [42], (2R)-8-methylsocotrin-4'-ol (69) [47], cochinchinenin [44], cochinchinenin B (75) [47], $(\gamma S)$-1-[5-(4,4'-dihydroxy-2-methoxydihydrochalconyl)]-1-(4-hydroxyph enyl)-3-(2-methoxy-4-hydroxy-phenyl)propane (cochinchinenin C) (76) [42,47], 1-[5-(2-methoxy-4,4' dihydroxydihydrochalconyl)]-1-(4-hydroxyphenyl)-3-(2-methoxy-4-hydroxy-phenyl)-propane [44,47], cochinchinenins D-H (structures 70,80,77,90,89 in Figures 12 and 13), cinnabarone (26) [39], dracaenin A (79) [42,54], socotrin-4'-ol (28) and homoisosocotrin- $4^{\prime}{ }^{\prime}$ ol (29)[40], cochinchinenins I-M (structures

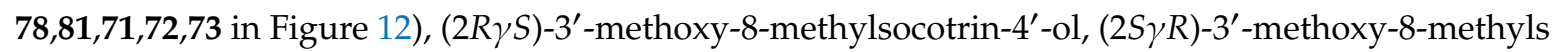


ocotrin-4'-ol, $(2 R \gamma R)-8$-methylsocotrin-4'-ol, (2R $\gamma S)$-8-methyl-socotrin-4' -ol [55-57], compound 74 [53], and biflavocochins A-G (structures 82-88 in Figure 13) [53].

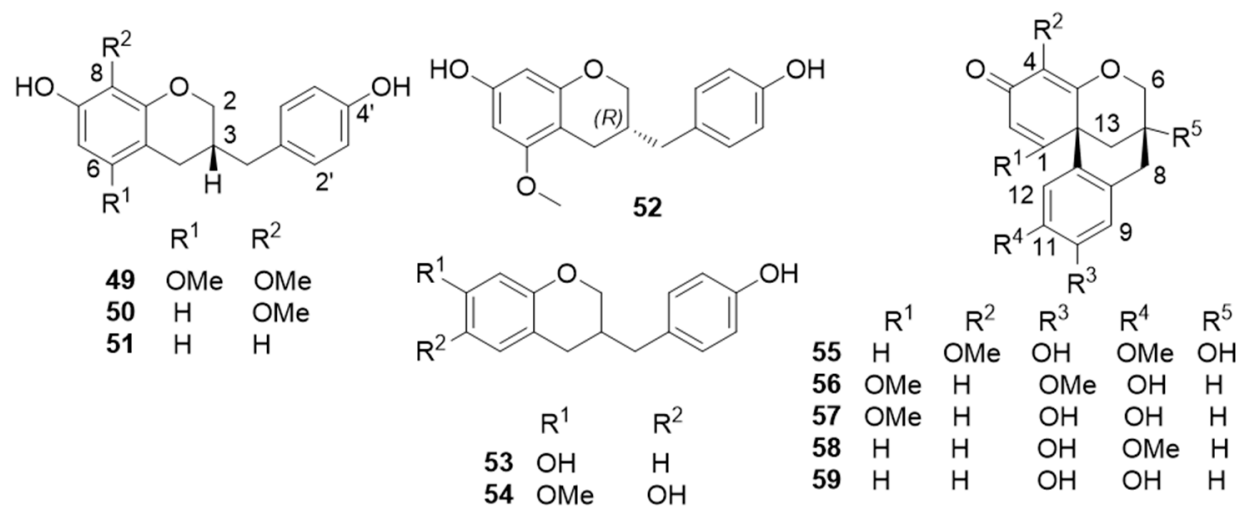

Figure 11. Selected homoisoflavans and meta-homoisoflavans from D. cochinchinensis red resin.

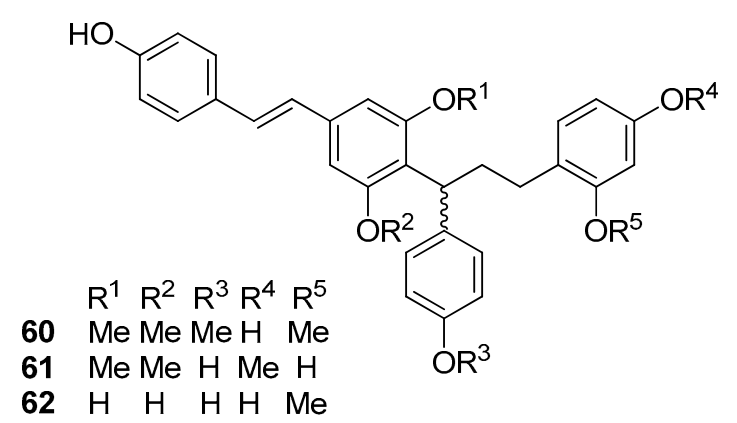<smiles>[R10]Oc1ccc([C@H](CCc2ccc([R20])cc2OC)c2cc(/C=C/c3ccc(O)cc3)cc(O[R])c2O[R])cc1</smiles>

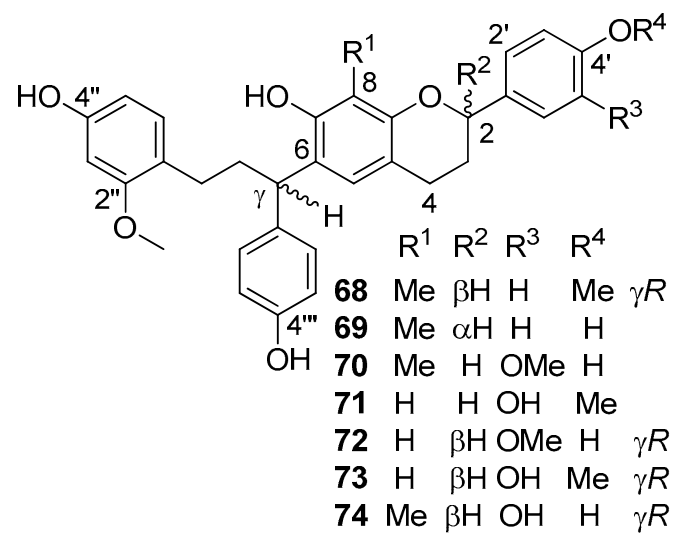

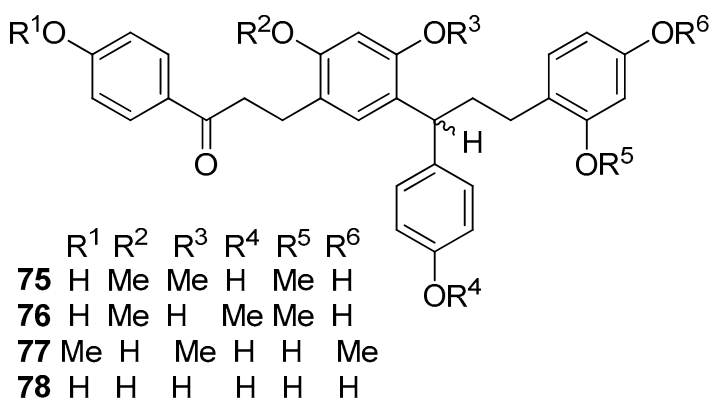<smiles>COc1cc(O)ccc1CC[C@@H](c1ccc(O)cc1)c1c(OC)c2ccc(-c3ccc(O)cc3)oc-2cc1=O</smiles><smiles>[R2]Oc1ccc(CC/C(=C(/c2ccc(O)cc2)c2cc3c(c([R])c2O)OC[C@H](Cc2ccc(O)cc2OC)C3)c2ccc(O)cc2)c([R12])c1</smiles>

Figure 12. Selected flavonoid dimers from $D$. cochinchinensis red resin. 
<smiles>COc1cc(C23C[C@H](c4ccc(O)cc4O2)c2c(cc(OC)c4c2OC[C@@H](Cc2ccc(O)cc2)C4)O3)ccc1O</smiles><smiles>COc1cc(OC)c2c(c1)O[C@@]1(c3ccc(O)cc3)C[C@H]2c2c(cc(OC)c(CCC(=O)c3ccc(O)cc3)c2O)O1</smiles>

84<smiles>COc1cc(C23C[C@H](c4ccc(O)cc4O2)c2c(cc(OC)c4c2OC[C@@H](Cc2ccc(O)cc2)C4)O3)ccc1O</smiles>

83<smiles>COc1cc(O)ccc1[C@@H]1CC(c2ccc(O)cc2)c2c(cc(OC)c3c2OC[C@H](Cc2ccc(O)cc2)C3)O1</smiles>

85<smiles>COC1=C(CCC(=O)c2ccc(O)cc2)C(O)=C(Cc2c(O)cc(OC)c3c2OC[C@@H](Cc2ccc(O)cc2)C3)C(O)C1</smiles><smiles>COc1ccc(C(=O)CCc2cc([C@H](CCc3cc(C(CCc4ccc(OC)cc4OC)c4ccc(O)cc4)c(O)cc3OC)c3ccc([Se])cc3)c(O)cc2OC)cc1</smiles><smiles>COc1cc(O)c(CC[C@H](c2ccc(O)cc2)c2cc3c(cc2O)O[C@@H](c2ccc(O)cc2)CC3)cc1[C@@H](CCc1ccc(O)c(C)c1OC)c1ccc(O)cc1</smiles><smiles>Cc1c(O)cc(O)cc1/C=C/c1ccccc1</smiles>

91

Figure 13. Selected flavonoid dimers (cont.) and trimers from D. cochinchinensis red resin. 
<smiles>COc1ccc(CC2(O)COc3c(C)c(OC)cc(O)c3C2=O)cc1</smiles>

\section{2}

Figure 14. Chemical structure of dracol isolated from D. draco.

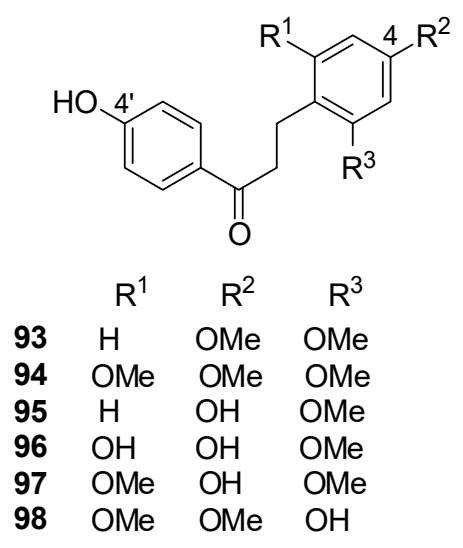<smiles>O=C1c2c(O)cc(O)cc2OCC1(O)Cc1ccc(O)cc1</smiles>

99

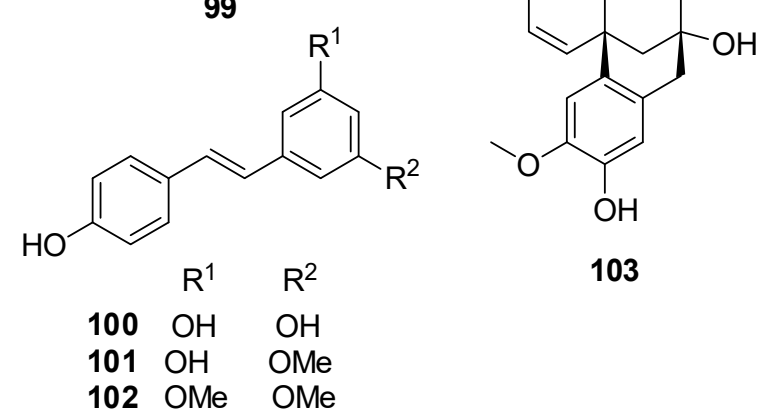

Figure 15. Chemical structures of compounds 93-103 isolated from D. loureiri.<smiles>COc1cc2c(c(O)c1O)C(=O)[C@](O)(Cc1ccc(O)cc1)CO2</smiles>

104

Figure 16. Chemical structure of compound 104 isolated from D. usambarensis.

It is worth noting that the names cochinchinenenes $\mathrm{G}$ and $\mathrm{H}$, at first attributed to compounds $\mathbf{6 7}$ and 62, respectively [44], were later also used for naming "compounds" 68 and 34, respectively [42].

(7E)-1,5-Dihydroxy-11,12,13-trimethoxystilbene, (7E)-1,5-dihydroxy-11,13-dimethoxystilbene, (7E)-2,4-dihydroxy-1-methylstilbene (structure 91 in Figure 13), 1,3-dihydroxy-2,4-dimethyl-5-metho xychalcone, (2S)-7,4'-dimethoxy-5-hydroxy-6-methylflavan, and (3S)-3,7-dihydroxy-4-methoxyhomoiso flavanone were identified by Niu and his co-workers in dragon's blood of D. cochinchinensis elicited by Fusarium graminearum [58]. Flavonoids and stilbenoids contained in other parts of the plant have been less investigated than the flavonoids isolated from the resin. (2S)-4',7-dihydroxy-3'-methoxy-8methylflavan, (2S)-7,3'-dihydroxy-4'-methoxy-8-methylflavan (9), 7-hydroxy-4'-methoxyhomoiso flavanone, (3R)-3,7-dihydroxy-8,4'-dimethoxyhomoisoflavanone, and 4,2', $4^{\prime}$-trihydroxychalcone were isolated from D. cochinchinensis leaves [59]. 7, $4^{\prime}$-Dihydroxy- homoisoflavanone $(42), 10,11$ dihydroxydracaenone C (59), 7,4'-dihydroxyflavone, 7,4'-dihydroxy-flavan, 4,4'-dihydroxy-2-methoxy chalcone (echinatin), 4,4'-dihydroxy-2-methoxydihydrochalcone, and 7,4' -homoisoflavan, together with sterols and phenolic glycosides, were isolated from fresh stems [60].

Compounds 49-51 and 45-47 did not show cytotoxic effects at a concentration of $10 \mu \mathrm{M}$, whereas they significantly promoted osteogenic differentiation of mesenchymal stem cells (MSCs) by increasing the levels of alkaline phosphatase (ALP) activity to $159.6 \pm 5.9 \%, 167.6 \pm 10.9 \%, 162.0 \pm 1.4 \%, 151.3 \pm 4.0 \%$, $171.0 \pm 8.2 \%$, and $169.9 \pm 7.3 \%$, respectively, relative to the control [49]. Compounds 72 and 73 showed significant inhibitory activities against NO production in lipopolysaccharide-stimulated BV-2 microglial cells with $\mathrm{IC}_{50}$ values of $4.9 \pm 0.4$ and $5.4 \pm 0.6 \mu \mathrm{M}$, respectively [56], whereas $\mathrm{IC}_{50}$ values of compounds 
41, 42, and 58 were in the range of 60.4-75.6 $\mu \mathrm{M}$ [52]. Apigenin, 7-hydroxy-3-(4-hydroxybenzylidene) chroman-4-one, compounds 8, 31-33, 52, and 68 exhibited significant anti-neuroinflammatory properties without showing cytotoxic effects at the tested concentrations. A primary mechanistic study revealed that these effective compounds could inhibit neuroinflammation by inhibiting NO production and reducing the expressions of iNOS, IL-6, and TNF- $\alpha$ in LPS-activated BV2 microglial cells [42]. Compounds 60, 63-65, 69, 75, 76, and 1-[5-(2-methoxy-4,4'-dihydroxydihydrochalconyl)]-1-(4-hydroxy phenyl)-3-(2-methoxy-4-hydroxyphenyl)- propane showed moderate thrombin inhibitory activity, whereas compounds $\mathbf{4 8}, \mathbf{7 5}$, and $\mathbf{7 6}$ were active against Helicobacter pylori (ATCC43504) with MIC values of 29.5, 29.5, and $31.3 \mu \mathrm{M}$, respectively [47]. Compounds $\mathbf{4 3}, \mathbf{5 8}, \mathbf{6 1}$, and $\mathbf{6 6}$ showed good NAD(P)H Quinone Dehydrogenase 1 (NQO1) inducing activities, whereas compounds 36, 37, 43, 46, 53, and 54 exhibited anti-inflammatory activities [43]. Compound $\mathbf{8 2}$ showed neuroprotective effect on serum deficiency-induced cellular damage in neuroendocrine PC12 cells (pheochromocytoma cells derived from the adrenal gland of Rattus norvegicus), whereas compounds 83,87 , and 88 exhibited moderate protein tyrosine phosphatase 1B (PTP1B) inhibitory activities [53]. Compound 91 exhibited potent antioxidant activity and a broad-spectrum of inhibitory activity against fungal strains, including Exserohilum turcicum, Bipolaris maydis, Curvularia lunata, and F. graminearum [58].

\subsubsection{Dracaena draco L.}

D. draco L. is native to India, the Canary Islands, Cape Verde, Madeira, and locally in Western Morocco. It is the natural symbol of Tenerife island. Independently, an Italian research group [61] and Gonzàlez and collaborators [62] isolated from the red resin of $D$. draco the following group of compounds: (2S)-7,4' -dihydroxy-3'-methoxy-8-methylflavan, (2S)-5,4'-dihydroxy-7-methoxy-8-methylflavan, (2S)7,4' -dihydroxy-3'-methoxyflavan, (2S)-7,4'-dihydroxy-8-methylflavan, (2S)-7,3'-dihydroxy-4' -methoxy8-methylflavan (9), 7,4'-dihydroxyhomoisoflavan, 7,4'-dihydroxy-8-methoxyhomoisoflavan, $4^{\prime}$-hydroxy5,7-dimethoxyhomoisoflavan, 4' -hydroxy-7,8-methylendioxy- homoisoflavan, 5,7,4'-trihydroxyhom oisoflavan, 10-hydroxy-11-methoxydracaenone (42), 3,4'-dihydroxy-7-methoxyflavone, liquiritigenin (7,4'-dihydroxyflavanone), 7,4' -dihydroxyhomoiso- flavanone, 5,7,4'-trihydroxy-6-methylhomoiso flavanone, 5,7,4' -trihydroxyhomoisoflavanone, 4, $4^{\prime}$-dihydroxy-2' -methoxychalcone, isoliquiritigenin (4,2', $4^{\prime}$-trihydroxychalcone), 2,4,4'-trihydroxy-dihydrochalcone, and loureirin C (4,4'-dihydroxy-2methoxydihydrochalcone) (8). Flavans of dragon's blood from D. draco L. subsp. draco (Tenerife and Cape Verde) and D. draco L. subsp. ajgal (Morocco) were identified as (2S)-7,3'-dihydroxy-4' -methoxy8-methylflavan (9), (2S)-7, $4^{\prime}$-dihydroxy-3'-methoxy-8-methylflavan, (2S)-7, $4^{\prime}$-dihydroxy-3'-methoxy flavan, (2S)-7, $4^{\prime}$-dihydroxy-8-methylflavan, and (2S)-5, $4^{\prime}$-dihydroxy-7-methoxy-8-methylflavan [63]. From samples of dragon's blood collected from ancients specimens of D. draco L. subsp. draco growing in Palermo, Di Stefano reported the isolation and structural characterization of 7,4'-dihydroxyflavan, 7,3'-dihydroxy-4'-methoxy-8-methylflavan, 7,4'-dihydroxy-3'-methoxy-8-methylflavan, 7,4'-dihydroxy3'-methoxy-flavan, 7,4' -dihydroxy-8-methylflavan, 5,4'-dihydroxy-7-methoxy-8-methylflavan, 7,4' dihydroxy-homoisoflavan, 7,4'-dihydroxy-8-methylhomoisoflavan, 7,4'-dihydroxy-8-methoxyhomoiso flavan, 7,4'-dihydroxy-5-methoxyhomoisoflavan, 7,4'-dihydroxyhomoisoflavanone, 5,7,4'-trihydroxy homo-isoflavanone, 5,8,4' -trihydroxy-7-methoxyhomoisoflavanone, 5,7,4' -trihydroxy-6-methoxyhomoisoflavanone, 5,7,4' -trihydroxy-6-methylhomoisoflavanone, and 5,7,4' -trihydroxy-6,8-dimethyl-homo isoflavanone [64]. Dracol (structure 92 in Figure 14), 5,7,4'-trihydroxyhomoisoflavanone, and helichrysetin were isolated from an $\mathrm{EtOH}$ extract of $D$. draco leaves [65]. Compound 92 was completely ineffective against HL-60 (leukemia), A431 (epidermoid), HeLa (cervix), and SK-OV-3 (ovarian) tumor cells $\left(\mathrm{IC}_{50}\right.$ values $\left.>100 \mu \mathrm{M}\right)$ [65]. Quercetin-3-O-rutinoside was identified in aqueous extract of $D$. draco fruits [13]. 4'-Hydroxy-7,8-methylendioxyhomoisoflavan, (2S)-7,4'-dihydroxy-8-methylflavan, 7,4' dihydroxy-8-methoxyhomoisoflavan, loureirins $\mathrm{A}$ and $\mathrm{C},(-)-7,3^{\prime}$-dihydroxy-4'-methoxy-8-methylflavan, 7,4'-dihydroxyhomoisoflavan, isoliquiritigenin. (2S)-7, $4^{\prime}$-dihydroxy-3' -methoxyflavan, and (2S)-5, $4^{\prime}$ dihydroxy-7-methoxy-8-methylflavan were isolated from $D$. draco roots [65]. Loureirin C (8), (2S)-7, $4^{\prime}-$ dihydroxy- $3^{\prime}$-methoxyflavan, and isoliquiritigenin $[66,67]$ were isolated from $D$. draco stem bark [67]. 


\subsubsection{Dracaena loureiri Gagnep}

D. loureiri Gagnep is a misspelled name for D. loureiroi Gagnep, which is considered illegitimate and synonym for Dracaena cochinchinensis (Lour.) S.C. Chen [68]. The plant is known by Thai's as 'Jun-Par' and is commonly referred to as "Thai Dracaena". This herb has positive activities of promoting blood circulation for removing blood stasis, regenerating tissue to heal wound, relieving pain, and eliminating swelling. It has been commonly used for the treatment of coronary heart diseases, angina, and acute myocardial infarction. Moreover, the EtOAc extract of D. loureiri can promote inflammatory response induced by LPS through inhibiting ROS production in vascular smooth muscle cells and macrophages. Meksuriyen and Cordell isolated loureirins A-D (structures 93-96 in Figure 15) from the leaves of the plant collected in Thailand [69]. Loureirin D (96) exhibited mild inhibition of LPS-stimulated NO production in RAW 264.7 macrophages, with an $\mathrm{IC}_{50}$ value of $50.3 \mu \mathrm{M}$, whereas it inhibited the activation of the IL-6/STAT3/NF- $\mathrm{BB}$ signaling pathway [48,70]. Ichikawa et al. isolated loureirins B (94) and D (96), 4,4'-dihydroxy-2,6-dimethoxydihydrochalcone (97), 2,4'-dihydroxy-4,6-dimethoxydihydrochalcone (98), 3,5,7-trihydroxy-4' -methoxyhomoisoflavanone (eucomol), 5,7,4'-trihydroxyhomoisoflavanone, and 7,4'-dihydroxy-5-methoxyhomoisoflavanone from the stem wood of the plant, a Thai folkloric medicine called "Chan-daeng" [71]. Likhitwitayawuid also isolated loureiriol (99), 4,6, $4^{\prime}$-trihydroxy-2-methoxydihydrochalcone, 4,3', $5^{\prime}$-trihydroxystilbene (100), 4,3'-dihydroxy-5'-methoxystilbene (101), and 4-hydroxy-3', 5'-dimethoxy- stilbene (102) [72]. Compounds 97 and 98 were estrogen agonist and stimulated the estrogen-dependent human breast adenocarcinoma MCF-7 cell proliferation in a concentration-dependent manner between $10^{-8}$ and $10^{-5}$ M. 5,7,4'-Trihydroxyhomoisoflavanone showed appreciable estrogenic activity, competing with $\left[{ }^{3} \mathrm{H}\right]$-estradiol for binding to the bovine uterine estrogen receptor. The apparent $\mathrm{IC}_{50}$ value was $375 \mathrm{nM}$, compared to the value of $225 \mathrm{nM}$ for genistein [71]. Compounds 100-102 showed potent inhibitory activity of COX-1 and COX-2 with $\mathrm{IC}_{50}$ values in the range between 1.29 and $4.92 \mu \mathrm{M}$ [72].

The bioactivities of loureirin B (94) are worthy of note. The compound can modulate the TTX-R sodium channel in DRG neurons via an AC/CAMP/PKA pathway that involves the activation of AC and PKA [73]. Another study confirmed that compound 94 promotes insulin secretion and lowers blood glucose level mainly through increasing mRNA level of $P d x-1$, MafA, and intracellular ATP level, and inhibiting $\mathrm{K}_{\text {ATP }}$ current and influx of intracellular $\mathrm{Ca}^{2+}$ [74]. Experiments on Crohn's disease (CD) rat model induced by 2,4,6-trinitrobenzenesulfonic acid (TNBS) indicated that loureirin B (94) can be beneficial for ameliorating the damage to colon length in a dose dependent manner. Moreover, loureirin B remarkably ameliorated TNBS-induced inflammatory response via regulation of cytokines in the colonic tissues, and inhibited apoptosis through regulation of IL-6/STAT3/NF- $\mathrm{KB}$ signaling pathway. This finding may represent a novel approach to treat $\mathrm{CD}$ and provides an alternative choice for disorders associated with CD [70]. Homoisoflavans 69 and 7,10-dihydroxy-11-methoxydracaenone (structure 103 in Figure 15) were isolated from a $\mathrm{CHCl}_{3}$ extract of the plant. They were inactive against S. aureus, Bacillus subtilis, and Escherichia coli (MIC > $250 \mu \mathrm{g} / \mathrm{mL}$ ) [75].

\subsubsection{Dracaena usambarensis Engl. (synonym for Dracaena mannii Baker)}

The plant is distributed from Senegal to Angola along the African west coast; it is widespread in tropical Africa and grows along the African east coast from Kenya to Kosi Bay in northern KwaZuluNatal. Separation of a root extract afforded 4,4'-dihydroxy-2,3-dimethoxydihydrochalcone, the homo isoflavonoid 7-O-methyl-8-demethoxy-3-hydroxy-3,9-dihydropunctatin, and the homoisoflavanones 99 and (3S)-3,5,6,4'-tetrahydroxy-7-methoxyhomoisoflavanone (structure 104 in Figure 16) [76]. Compound 104 showed moderate cytotoxic effects against drug sensitive human lymphoblastic leukemia CCRF-CEM T cells; instead, it was inactive against all the other tested cell lines, including leukemia (CEM/ADR5000), human breast adenocarcinoma (MDA-MB-231-pcDNA3 and MDA-MB-231-BCRP clone 23), human glioblastoma (U87.MG and the resistant subline U87.MG $\triangle$ EGFR), human hepatocyte carcinoma (Hep G2), and healthy hepatocyte (AML12) cell lines [76]. 


\subsubsection{Other Dracaena spp.}

(2S)-7,4'-Dihydroxy-8-methylflavan and (2S)-5,4'-dihydroxy-7-methoxy-8-methylflavan were isolated from the dragon's blood of Dracaena tamaranae Marrero Rodr., R. S. Almeira, and M. GonzalesMartin (Gran Canaria) [63]. The common flavonoids rutin, kaempferol, and quercetin were isolated from a methanolic extract of the leaves of Dracaena ombet Heuglin ex Kotschy and Peyr. [77]. Kaempferol 3-O- $\alpha$-L-rhamnopyranosyl-( $1 \rightarrow 2)-O-[\alpha$-L-rhamnopyranosyl- $(1 \rightarrow 6)]-\beta$-D-galacto-pyranoside and kaempferol 3-O- $\alpha$-L-rhamnopyranosyl-( $1 \rightarrow 2)$-O-[ $\alpha$-L-rhamnopyranosyl-( $1 \rightarrow 6)]-\beta$-D-glucopyranoside were isolated from the leaves of Dracaena thalioides Makoy ex E. Morris, a perennial plant native to tropical regions of Africa [78].

\subsubsection{Colorants of Dragon's Blood Resins}

Different red colorants, namely, dracaenin A (79) [42,54] (Figure 12), nordrachorhodin (105), dracorhodin (106), dracoflavilium (107/108), and dracorubin (109) (Figure 17), have been isolated from dragon's blood resins obtained from different Dracaena trees [79]. The compounds share a common chromophore constituted by three conjugated rings forming a 2-phenyl-1-benzopyran moiety.
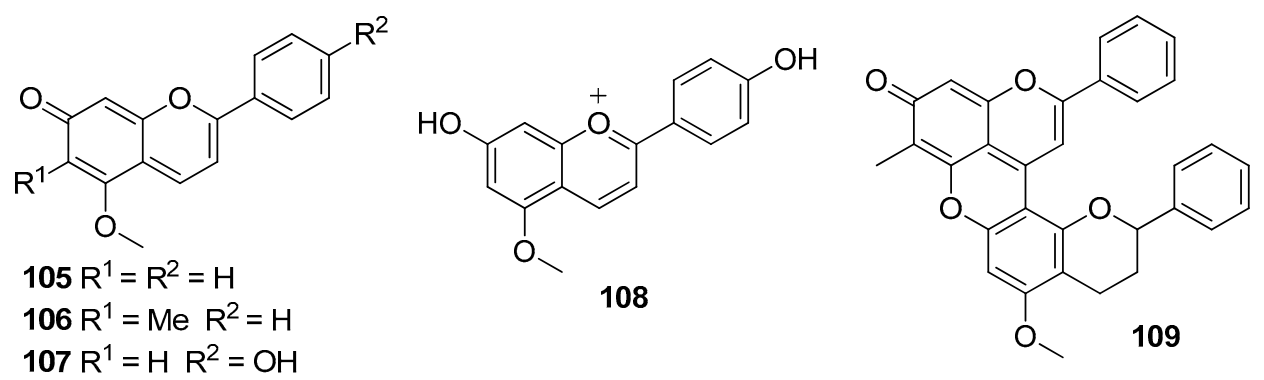

Figure 17. Chemical structures of compounds 105-109 responsible for the red color of dragon's blood resin from Dracaena species.

These compounds undergo multiple structural transformations in aqueous acidic and basic solution, following the same basic mechanisms, that were completely characterized in the case of 7,4'-dihydroxy-5-methoxyflavilium, called dracoflavilium (107/108) [79]. This colorant was isolated from a resin extracted from $D$. draco centenary trees existing in the region of Lisbon and Madeira island; the structure was confirmed by total synthesis [79]. Dragon's blood is yellow in strongly acidic aqueous solutions, because the species present is the flavylium cation 108. At moderately acidic $\mathrm{pH}$ values, the red quinoid base $\mathbf{1 0 7}$ is formed which absorbs at about $550 \mathrm{~nm}$. This base is the major species $(63 \%)$ at biological $\mathrm{pH}$ (ca. 6) and gives the resin the characteristic red color (Figure 1a). The remaining species $(37 \%)$ in the equilibrium is the pale-yellow $(E)$-chalcone 110. Ionized $(E)$-chalcone 111 and the predominant pink deprotonated quinoid base 112 are present at $\mathrm{pH}=8-9$, whereas the double deprotonated base $\mathbf{1 1 3}$ is the only species occurring at $\mathrm{pH}=12$ (Figure 18) [79].<smiles>COc1cc(O)cc(O)c1/C=C/C(=O)c1ccc(O)cc1</smiles><smiles>COc1cc([O-])cc(O)c1/C=C/C(=O)c1ccc(O)cc1</smiles><smiles>COc1cc(=O)cc2oc(-c3ccc([O-])cc3)ccc1-2</smiles><smiles>COc1cc([O-])cc(O)c1/C=C/C(=O)c1ccc([O-])cc1</smiles>

Figure 18. Species 110-113 in equilibrium with dracoflavilium (107/108) in aqueous solution at different $\mathrm{pH}$. 


\subsection{Sansevieria Species}

\subsubsection{Sansevieria cylindrica Bojer ex Hook. (Dracaena angolensis (Welw. ex Carrière) Byng \& Christenh)}

Sansevieria cylindrica (Figure 1c), known with the indigenous names of cylindrical snake plant, African spear, spear sansevieria, and Saint Bárbara sword in Brazil, is a succulent plant native to Angola. In addition to ornamental uses, the whole plant is used in Myanmar traditional medicine for treating cuts, sprains, and broken bones, whereas the roots are used to cure snakebites. The hydroxy methyldihydrochalcone (1,2-seco-homoisoflavanone) (+)-2' ,4'-dihydroxy-3'-methoxy-3,4-methylene dioxy-8-hydroxymethyldihydrochalcone, named (+)-(8S)-trifasciatine C (114), was isolated from the aerial parts of $S$. cylindrica [80]. It showed moderate cytotoxic effects against human breast adenocarcinoma (MCF7) cells. From the aerial parts of S. cylindrica Said et al. also isolated 3,7-dihydroxy8-methoxy-3-( $3^{\prime}, 4^{\prime}$-methylenedioxybenzyl) chroman-4-one, named (+)-(3S)-trifasciatine B (116 $\equiv$ ent-127). This compound exhibited significant DPPH radical scavenging activity $\left(\mathrm{IC}_{50} 35.2 \mu \mathrm{g} / \mathrm{mL}\right.$ ), that was comparable with that of ascorbic acid ( $\mathrm{IC}_{50} 33.3 \mu \mathrm{g} / \mathrm{mL}$ ) [81]. Phytochemical investigations of S. cylindrica rhizomes, collected in Myanmar, revealed the presence of $(-)-(8 R)$-trifasciatine $C$ (115 $\equiv$ ent-114), homoisoflavanones (-)-(3R)-trifasciatine A (126), (+)-trifasciatine B (116), compounds 117-120 (Figure 19), and (-)-cambodianol (20) [30], along with the furanoflavones lanceolatin B (121) and pongaglabol methyl ether (122), the flavone de(s)methoxy-kanugin (123), and the pterocarpan $(-)-(6 a R, 11 a R)$-homopterocarpin (124) [82,83].<smiles>COc1c(O)ccc(C(=O)[C+](CO)Cc2ccc3c(c2)OCO3)c1O</smiles>

114<smiles>COc1c(O)ccc(C(=O)[C@H](CO)Cc2ccc3c(c2)OCO3)c1O</smiles>

115<smiles>[R6]c1ccc(C[C@]2([R5])COc3c([R4])c([R6])c([R2])c([R])c3C2=O)cc1[R6]</smiles>

$\begin{array}{llllllll} & \mathrm{R}_{1} & \mathrm{R}_{2} & \mathrm{R}_{3} & \mathrm{R}_{4} & \mathrm{R}_{5} & \mathrm{R}_{6} & \mathrm{R}_{7} \\ 116 & \mathrm{H} & \mathrm{H} & \mathrm{H} & \mathrm{OMe} & \alpha-\mathrm{OH} & -\mathrm{CH}_{2} \mathrm{OCH}_{2} \\ 117 & \mathrm{OH} & \mathrm{Me} & \mathrm{Me} & \mathrm{H} & \alpha-\mathrm{OH} & \mathrm{OMe} & \mathrm{H} \\ 118 & \mathrm{OH} & \mathrm{H} & \mathrm{Me} & \mathrm{H} & \alpha-\mathrm{OH} & \mathrm{OMe} & \mathrm{H} \\ 119 & \mathrm{OH} & \mathrm{Me} & \mathrm{Me} & \mathrm{H} & \alpha-\mathrm{OH} & \mathrm{OH} & \mathrm{H} \\ 120 & \mathrm{OH} & \mathrm{H} & \mathrm{Me} & \mathrm{H} & \alpha-\mathrm{OH} & \mathrm{OH} & \mathrm{H}\end{array}$<smiles>[R]c1cc2occc2c2oc(-c3ccccc3)cc(=O)c12</smiles><smiles>COc1ccc2c(=O)c(OC)c(-c3ccc4c(c3)OCO4)oc2c1</smiles>

123<smiles>COc1ccc2c(c1)OC[C@H]1c3ccc(OC)cc3O[C@H]21</smiles>

124

Figure 19. Chemical structures of compounds 114-124 isolated from S. cylindrica.

Compounds 115, 116-120 displayed weak radical scavenging activity in the DPPH test $\left(\mathrm{EC}_{50}\right.$ values $>100 \mathrm{mM}$ ) [82]. Lanceolatin B (121) showed high cancer chemopreventive potential [84], and anti-neuroinflammatory and analgesic properties [85].

\subsubsection{Sansevieria roxburghiana Schult. \& Schult. f.}

The homoisoflavanone (-)-(3R)-cambodianol (20) was claimed to have been isolated from a $\mathrm{MeOH}$ extract of S. roxburghiana [86]. However, recent careful examination of the NMR spectra of the compound 
led to a revision of the structure. In fact, the correct structure corresponds to that of compound $\mathbf{1 2 5}$ (Figure 20), that is the enantiomer of homoisoflavanone $\mathbf{1 1 9}$ isolated from S. cylindrica [82,83].<smiles>COc1cc2c(c(O)c1C)C(=O)C(O)(Cc1ccc(O)cc1)CO2</smiles>

Figure 20. Chemical structure of compound 125 isolated from S. roxburghiana.

\subsubsection{Sansevieria trifasciata Prain (Dracaena trifasciata (Prain) Mabb)}

Tchegnitegni and collaborators isolated two sappanin-type homoisoflavonoids, named trifasciatine A (126) and (-)-(3R)-trifasciatine B (127 $\equiv$ ent-116) (Figure 21), from the EtOAc soluble fraction of a methanol extract of $S$. trifasciata [87]. Dihydrochalcone (+)-(8S)-trifasciatine C (114) was isolated from the aerial parts [88].

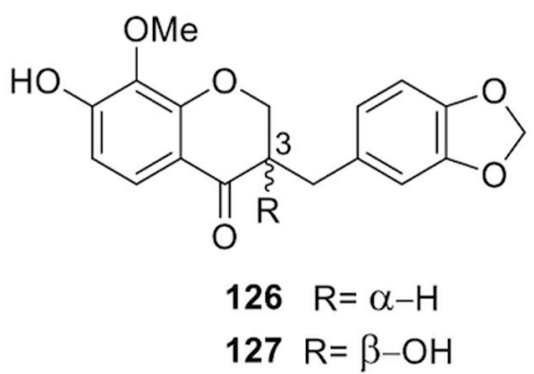

Figure 21. Chemical structures of compounds $\mathbf{1 2 6}$ and $\mathbf{1 2 7}$ isolated from S. trifasciata.

\section{Chemical Structures and Chemotaxonomic Considerations}

A wide variety of flavonoids and stilbenoids have been isolated from Dracaena species. They cover the families of flavones (e.g., 31), flavans (e.g., 2), flavanones (e.g., 12), homoisoflavans (e.g., 22), meta-homoisoflavans (e.g., 55), homoisoflavones (e.g., 3), homoisoflavanones (e.g., 13), chalcones (e.g., 10), dihydrochalcones (e.g., 7), chalcanes (e.g., 34), stilbenes (e.g., 43), and flavonoid dimers and trimers. Dimeric structures include flavan-flavan (e.g., 15), chalcane-flavan (e.g., 17), chalcone-dihydrochalcone (e.g., 24), chalcane-dihydro chalcone (e.g., 26), chalcane-homoisoflavan (e.g., 29), chalcane-stilbene (e.g., 60), chalcane-flavilium (e.g., 79), homoisoflavan-stilbene (e.g., 82), dihydrochalcone-stilbene (e.g., 84), and dihydrochalcone-homoisoflavan dimers (e.g., 86). Other dimers include a stilbene-phenylpropanoid dimer (44) and flavan-phenylpropanoid dimers (e.g., 5). Trimeric structures include chalcane-chalcane-flavan (e.g., 25), chalcane-chalcane-chalcane (e.g., 30), and dihydrochalcone-chalcane-chalcane trimers (e.g., 89). Interestingly, in contrast to these flavonoids, Dracaena anthocyanidins and anthocyanidin have poorly been characterized. Moreover, it is worth noting that the absolute configurations of several flavans, homoisoflavans, homoisoflavanones, and flavonoid dimers and trimers have not been determined. Nonetheless, the stereochemistry should be assigned, both for completing the structural determination of isolated compounds and for a better understanding of compound bioactivities.

Among flavonoid families, dihydrochalcones, flavans, homoisoflavans, meta-homoisoflavans, and oligomers appear to be diagnostic chemical clusters in Dracaena species. Loureins A (36) and B (37) are often used as the chemical markers for the quality control of dragon's blood.

In contrast to the wide variety of Dracaena flavonoids, the chemical families mostly occurring in Sansevieria species are only flavones (e.g., 121) and homoisoflavanones (e.g., 116). This finding may depend on the fact that, compared with Dracaena species, less phytochemical studies have been devoted to Sansevieria spp. Moreover, Dracaena flavonoids have mostly been isolated from red resins, 
while those identified in Sansevieria have been found in extracts of aerial parts and rhizomes. Interestingly, the pterocarpan 124 and the 8-hydroxymethyldihydrochalcones (1,2-seco-homoisoflavanones) 114 and 115, isolated from two Sansevieria spp., are the only examples of such structures occurring in the two groups of plants. In addition to flavones, homoisoflavanones are the only flavonoids isolated from both Sansevieria and Dracaena species, although they display different substitution patterns. In fact, compared with Dracaena homoisoflavanones, the structures of the corresponding derivatives from Sansevieria spp. usually contain more $O$ - and $C$-alkyl substituents; moreover, a hydroxy group is often bonded to C3. Enantiomeric trifasciatines B (116 and 127) and C (114 and 115), and homoisoflavanones 119 and 125 are examples of antipodal congeners occurring in different species of the same genus. More interesting is the isolation of enantiomeric compounds from different parts of the same plant. Thus, (+)-(8S)-trifasciatine C (114) was isolated from aerial parts of S. cylindrica [80], while the (8R)-enantiomer (115) was isolated from rhizomes [82]. Two different biosynthetic routes have been proposed to explain the formation of such antipodal flavonoids. Enantiodivergent biosynthetic reactions are involved that stem from achiral intermediates [82,87]. The isolation of homoisoflavonoids appears to have chemotaxonomic significance, because the largest number have been associated with Asparagaceae, Fabaceae and, to a minor extent, Liliaceae and Orchidaceae families [89].

\section{Biological and Pharmacological Properties}

The biological and pharmacological activities determined for dragon's blood, crude and enriched extracts from Dracaena spp. are described in detail in reference [8]. These properties include analgesic, anti-inflammatory, antibacterial, hypolipidemic, hypoglycemic, and cytotoxic activities, as well as bidirectional regulation of hemorheology and cardiovascular and cerebrovascular effects. Pharmacological activities determined for individual flavonoids and stilbenoids isolated from Dracaena and Sansevieria species are summarized in Table 1. Standard in vitro biological assays have usually been carried out to measure the effects reported in the Table.

Especially remarkable are the anti-inflammatory activities of cochinchinenins L (72) and M (73) [56], and pterostilbene (43) [43], and the anti-neuroinflammatory properties of 4,4'-dihydroxy-2-methoxy dihydrochalcone (8), flavones 31-33, and homoisoflavan 59 [42]. The high cytotoxic effects exhibited by cambodianol (20) [30,31] and 4,4'-dihydroxy-3,2'-dimethoxychalcone [32] against different cell lines in an MTT assay are comparable with those the very well-known anti-cancer chemotherapy drugs paclitaxel and mitomycin C. The osteogenic effects of compounds 45-47, 49-51 [49] and the thrombin-inhibiting activities of cochinchinenene A (60) and cochinchinenin C (76) [47] are highly interesting. The inhibitory activities of the pro-inflammatory enzymes COX-1 and COX-2 by compounds 100-102 [72], as well as the PTP1B inhibitory activities of biflavocochins B (83), F (87), and G (88) [53], the multifaceted activities of loureirin B (94) $[69,72,73]$, and the high cancer chemopreventive potential, anti-neuroinflammatory, and analgesic properties of lanceolatin B (121) are also worthy of note [84,85].

It must be stressed that in vivo pharmacological studies of the activities and underlying mechanisms of dragon's blood and extracts from Dracaena and Sansevieria species are still incomplete or had an inappropriate scientific approach. The results are thus scientifically invalid [8]. Therefore, although these natural remedies have attractive potential therapeutic effects on different diseases, especially for the treatment of cardiovascular and cerebrovascular diseases, there is an urgent need to conduct experiments on appropriate cell lines and animal models under scientifically correct protocols, before they can enter into clinical trials [8]. The same conclusion holds for individual flavonoids and stilbenes; namely, more scientific experiments, especially in vivo, must be performed before promising bioactive compounds can be promoted as approved effective drugs. 
Table 1. Biological/pharmacological activities of characteristic flavonoids and stilbenoids isolated from Dracaena and Sansevieria species.

\begin{tabular}{l}
\hline Source(s) and Compound(s) \\
\hline Dracaena angustifolia \\
\hline (2R)-3',7-dihydroxy-5',5-dimethoxy-8-methylflavone (2) \\
desmethylisoophiopogonone B (3) \\
5,7,4'-trihydroxyhomoisoflavanone (4) \\
\hline Dracaena cambodiana
\end{tabular}

cambodianins A (5) and B (6);

4, $4^{\prime}$-dihydroxy-2'-methoxychalcone (11)

(3R)-7, $4^{\prime}$-dihydrohomoisoflavanone (13)

( \pm -) 7,4'-dihydroxyhomoisoflavanone

4,4'-dihydroxy-2,3'-dimethoxydihydrochalcone (7)

$4,4^{\prime}$-dihydroxy-2-methoxydihydrochalcone (8)

cambodianins D (14) and E (15)

(2S)-7,4'-dihydroxy-6,8-dimethylflavan (16)

cambodianin G (18)

cambodianin H (19)

cambodianol (20)

Biological/pharmacological Activities

References

Anti-inflammatory activity: $2\left(\mathrm{IC}_{50}=45 \mu \mathrm{M}\right) ; 3\left(\mathrm{IC}_{50}=33 \mu \mathrm{M}\right) ; 4\left(\mathrm{IC}_{50}=61 \mu \mathrm{M}\right)$

[23]

ytotoxic effects against chronic myelogenous leukemia K-562 (5, IC $50=13.300 \pm 0.064 \mu \mathrm{g} / \mathrm{mL}$

6, $\mathrm{IC}_{50}=14.100 \pm 0.042 \mu \mathrm{g} / \mathrm{mL} ; \mathbf{1 1}, \mathrm{IC}_{50}=32.500 \pm 0.082 \mu \mathrm{g} / \mathrm{mL} ; \mathbf{1 3}$,

$\left.\mathrm{IC}_{50}=15.600 \pm 0.040 \mu \mathrm{g} / \mathrm{mL}\right)$, human hepatocarcinoma SMMC-7721 (6,

$\left.\mathrm{IC}_{50}=25.000 \pm 0.025 \mu \mathrm{g} / \mathrm{mL} ; \mathbf{1 1}, \mathrm{IC}_{50}=12.500 \pm 0.025 \mu \mathrm{g} / \mathrm{mL} ; \mathbf{1 3}, \mathrm{IC}_{50}=30.200 \pm 0.022 \mu \mathrm{g} / \mathrm{mL}\right), \quad$ [24

and human gastric tumor SGC-7901 $\left(6, \mathrm{IC}_{50}=68.000 \pm 0.226 \mu \mathrm{g} / \mathrm{mL} ; \mathbf{1 1}\right.$,

$\mathrm{IC}_{50}=11.000 \pm 0.018 \mu \mathrm{g} / \mathrm{mL} ; 13, \mathrm{IC}_{50}=20.500 \pm 0.082 \mu \mathrm{g} / \mathrm{mL}$ ) cell lines.

Antibacterial activity against Staphylococcus aureus and methicillin-resistant S. aureus (MRSA)

Moderate cytotoxic effects against human myeloid leukemia (K562) and human gastric tumor (SGC-7901) cell lines $\left(\mathrm{IC}_{50}=16-29 \mu \mathrm{g} / \mathrm{mL}\right)$

Antibacterial activity against $S$. aureus and MRSA

$[24,25]$

Cytotoxic effects against K-562 $\left(\mathrm{IC}_{50}=9.5 \mu \mathrm{g} / \mathrm{mL}\right)$ and SGC-7901 $\left(\mathrm{IC}_{50}=16.2 \mu \mathrm{g} / \mathrm{mL}\right)$ cell lines; antibacterial activity against $S$. aureus Antibacterial activity against $S$. aureus

Cytotoxic effects against K562 ( $\left.\mathrm{IC}_{50}=1.4 \mu \mathrm{g} / \mathrm{mL}\right)$, SGC-7901 $\left(\mathrm{IC}_{50}=2.9 \mu \mathrm{g} / \mathrm{mL}\right)$ and SMMC-7721 $\left(\mathrm{IC}_{50}=5.0 \mu \mathrm{g} / \mathrm{mL}\right)$ cell lines, comparable with the values of paclitaxel

8-methylsocotrin-4'-ol Moderate cytotoxic effects against K562 and SGC-7901 cell lines

[31]

4,4'-dihydroxy-3,2'-dimethoxychalcone Cytotoxic effects against K562, SMMC-7721, and SGC-7901 cell lines, with $\mathrm{IC}_{50}$ values of 2.5, 4.3, and $4.4 \mathrm{mg} / \mathrm{mL}$, respectively, comparable with the values of mitomycin C

(2R)-7,4'-dihydroxy-6-methylflavan (21)

Weak cytotoxic effects $\left(\mathrm{IC}_{50}=39.22 \mu \mathrm{M}\right)$ against human hepatocellular carcinoma BEL-7402 cell line

(3R)-7, $3^{\prime}, 4^{\prime}$-trihydroxyhomoisoflavan (22) Acetylcholinesterase (AChE) inhibitory activity 
Table 1. Cont

\begin{tabular}{|c|c|c|}
\hline Source(s) and Compound(s) & Biological/pharmacological Activities & References \\
\hline \multicolumn{3}{|l|}{ Dracaena cinnabari } \\
\hline $4^{\prime}$-hydroxy-7,8-methylenedioxyhomoisoflavan (23) & $\begin{array}{l}\text { Inhibition of NO (nitric oxide), TNF- } \alpha \text {, and IL- } 6 \text { production in lipopolysaccharide stimulated } \\
\text { mouse macrophage RAW } 264.7 \text { cells }\end{array}$ & [36] \\
\hline dracidione (24) & $\alpha$-Glucosidase inhibitory activity $\left(\mathrm{IC}_{50}=40.27 \mu \mathrm{g} / \mathrm{mL}\right)$ & [37] \\
\hline \multicolumn{3}{|l|}{ Dracaena cochinchinensis } \\
\hline 4,4'-dihydroxy-2-methoxydihydrochalcone (8) & Anti-neuroinflammatory effects $\left(\mathrm{IC}_{50}=10.29 \pm 1.05 \mu \mathrm{M}\right)$ & [42] \\
\hline $\begin{array}{l}\text { apigenin } \\
\text { 7-hydroxy-3-(4-hydroxybenzylidene)chroman-4-one } \\
\text { 7,3'-dihydroxy-4'-methoxyflavone (31) } \\
\text { 7,4'-dihydroxyflavone (32) } \\
\text { 7-hydroxyflavone (33) }\end{array}$ & $\begin{array}{l}\text { Remarkable anti-neuroinflammatory activity (inhibition of NO production): } \\
\text { apigenin }\left(\mathrm{IC}_{50}=3.12 \pm 1.27 \mu \mathrm{M}\right) ; 7 \text {-hydroxy-3-(4-hydroxybenzylidene) chroman-4-one } \\
\left(\mathrm{IC}_{50}=4.46 \pm 0.95 \mu \mathrm{M}\right) ; 31\left(\mathrm{IC}_{50}=4.31 \pm 1.79 \mu \mathrm{M}\right) ; 32\left(\mathrm{IC}_{50}=8.00 \pm 2.04 \mu \mathrm{M}\right) ; 33 \\
\left(\mathrm{IC}_{50}=3.36 \pm 1.67 \mu \mathrm{M}\right)\end{array}$ & [42] \\
\hline 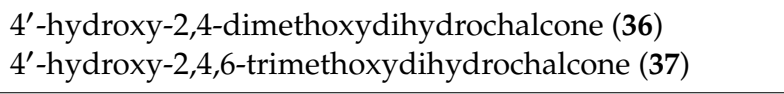 & Anti-inflammatory activity & [43] \\
\hline $\begin{array}{l}(3 S)-3,7,4^{\prime} \text {-trihydroxy-5-methoxyhomoisoflavanone }(\mathbf{4 1}) \\
\text { 7,4'-dihydroxyhomoisoflavanone }(\mathbf{4 2})\end{array}$ & $\begin{array}{l}\text { Inhibitory activity against nitric oxide }(\mathrm{NO}) \text { production: } \mathbf{4 1}\left(\mathrm{IC}_{50}=75.6 \pm 1.2 \mu \mathrm{M}\right) \text {; } \\
\mathbf{4 2}\left(\mathrm{IC}_{50}=60.4 \mu \mathrm{M}\right)\end{array}$ & [52] \\
\hline pterostilbene (43) & NQO1 [NAD(P)H Quinone Dehydrogenase 1] inducing activity and anti-inflammatory effects & [43] \\
\hline 7,4'-dihydroxy-8-methylflavan (45) & Osteogenic effects on mesenchymal stem cells (MSCs) & [49] \\
\hline 5,4'-dihydroxy-7-methoxy-6-methylflavan (46) & Osteogenic effects on mesenchymal stem cells (MSCs) and anti-inflammatory activity & {$[43,49]$} \\
\hline 7,4'-dihydroxyflavan (47) & Osteogenic effects on mesenchymal stem cells (MSCs) & [49] \\
\hline (2S)-7,4'-dihydroxy-8-methylflavan (48) & Antibacterial activities against Helicobacter pylori $(\mathrm{MIC}=31.3 \mu \mathrm{M})$ & [47] \\
\hline $\begin{array}{l}\text { dracaeconolide B (49) } \\
(3 R)-7,4^{\prime} \text {-dihydroxy-8-methoxyhomoisoflavan (50) } \\
(3 R)-7,4^{\prime} \text {-dihydroxyhomoisoflavan (51) }\end{array}$ & Osteogenic effects on mesenchymal stem cells (MSCs) & [49] \\
\hline (3R)-7,4'-dihydroxy-5-methoxyhomoisoflavan (52) & Anti-neuroinflammatory activity $\left(\mathrm{IC}_{50}=8.50 \pm 1.28 \mu \mathrm{M}\right)$ & [42] \\
\hline $\begin{array}{l}\text { 7,4'-dihydroxyhomoisoflavan (53) } \\
6,4^{\prime} \text {-dihydroxy-7-methoxyhomoisoflavan (54) }\end{array}$ & Anti-inflammatory activity & [43] \\
\hline 10-hydroxy-11-methoxydracaenone (58) & Inhibitory activity against NO production $\left(\mathrm{IC}_{50}=62.4 \pm 3.5 \mu \mathrm{M}\right)$ and NQO1 inducing activity & {$[43,52]$} \\
\hline cochinchinenene F (61) & NQO1 inducing activity & [43] \\
\hline
\end{tabular}


Table 1. Cont

\begin{tabular}{|c|c|c|}
\hline Source(s) and Compound(s) & Biological/pharmacological Activities & References \\
\hline cochinchinenenes A (60), B (63), C (64), and D (65) & $\begin{array}{l}\text { Thrombin inhibitory activity: } 60\left(\mathrm{IC}_{50}>9.5 \mu \mathrm{M}\right) ; 63\left(\mathrm{IC}_{50}=17.8 \mu \mathrm{M}\right) ; 64\left(\mathrm{IC}_{50}=26.7 \mu \mathrm{M}\right) \text {; } \\
65\left(\mathrm{IC}_{50}>41.3 \mu \mathrm{M}\right)\end{array}$ & [47] \\
\hline cochinchinenene E (66) & NQO1 inducing activity & {$[43]$} \\
\hline "cochinchinenene G" (68) & Inhibitory activity against NO production $\left(\mathrm{IC}_{50}=2.18 \pm 1.43 \mu \mathrm{M}\right)$ & [52] \\
\hline (2R)-8-methylsocotrin- $4^{\prime}$-ol (69) & Thrombin inhibitory activity $\left(\mathrm{IC}_{50}=21.5 \mu \mathrm{M}\right)$ & [47] \\
\hline cochinchinenins L (72) and M (73) & $\begin{array}{l}\text { Inhibitory effects on NO production in lipopolysaccharide (LPS)-stimulated BV-2 microglial cells: } \\
72\left(\mathrm{IC}_{50}=4.9 \pm 0.4 \mu \mathrm{M}\right) ; 73\left(\mathrm{IC}_{50}=5.4 \pm 0.6 \mu \mathrm{M}\right)\end{array}$ & [56] \\
\hline cochinchinenin C (76) & $\begin{array}{l}\text { Thrombin inhibitory activity }\left(\mathrm{IC}_{50}>9.2 \mu \mathrm{M}\right) \text {; antibacterial activity against Helicobacter pylori } \\
(\mathrm{MIC}=29.5 \mu \mathrm{M})\end{array}$ & [47] \\
\hline $\begin{array}{l}\text { 1-[5-(2-methoxy-4,4'-dihydroxydihydrochalconyl)]- } \\
\text { 1-(4-hydroxyphenyl)-3-(2-methoxy-4- } \\
\text { hydroxyphenyl)propane }\end{array}$ & Thrombin inhibitory activity $\left(\mathrm{IC}_{50}=26.3 \mu \mathrm{M}\right)$ & [47] \\
\hline biflavocochin A (82) & $\begin{array}{l}\text { Neuroprotective effect on serum deficiency-induced cellular damage in neuroendocrine PC12 } \\
\text { cells (pheochromocytoma cells derived from the adrenal gland of Rattus norvegicus) }\end{array}$ & [53] \\
\hline biflavocochins B (83), F (87), and G (88) & Protein-tyrosine phosphatase 1B (PTP1B) inhibitory activity & [53] \\
\hline (7E)-2,4-dihydroxy-1-methylstilbene (91) & $\begin{array}{l}\text { Antioxidant activity and antifungal activity against Exserohilum turcicum, Bipolaris maydis, } \\
\text { Curvularia lunata, and Fusarium graminearum }\end{array}$ & [58] \\
\hline \multicolumn{3}{|l|}{ Dracaena loureiri } \\
\hline loureirin B (94) & $\begin{array}{l}\text { Modulatory activity on the TTX-R sodium channel in dorsal root ganglion (DRG) neurons; } \\
\text { effect on insulin secretion of pancreatic } \beta \text {-cells, increase of the mRNA level of } P d x-1, M a f A \text {, } \\
\text { and intracellular ATP level; suppression of inflammatory cytokines and inhibition of apoptosis } \\
\text { through regulation of IL-6/STAT3/NF- }- \text { B signalling pathway }\end{array}$ & {$[70,73,74]$} \\
\hline loureirin D (96) & $\begin{array}{l}\text { Inhibition of NO production stimulated by } \\
\text { LPS-activated RAW } 264.7 \text { murine macrophages }\left(\mathrm{IC}_{50}=50.3 \mu \mathrm{M}\right)\end{array}$ & {$[48,70]$} \\
\hline $\begin{array}{l}\text { 4, } 4^{\prime} \text {-dihydroxy-2,6-dimethoxydihydrochalcone (97) } \\
\text { (also isolated from D. cambodiana) }\end{array}$ & $\begin{array}{l}\text { Cytotoxic effects against } \mathrm{K}-562\left(\mathrm{IC}_{50}=12.800 \pm 0.015 \mu \mathrm{g} / \mathrm{mL}\right), \mathrm{SMMC}-7721 \\
\left(\mathrm{IC}_{50}=16.200 \pm 0.040 \mu \mathrm{g} / \mathrm{mL}\right) \text {, and SGC-7901 }\left(\mathrm{IC}_{50}=10.000 \pm 0.060 \mu \mathrm{g} / \mathrm{mL}\right) \text { cell lines; } \\
\text { antibacterial activities against S. aureus; } \\
\text { stimulation of the hormone-dependent MCF-7 cell growth in a concentration dependent manner } \\
\text { between } 10^{-8} \text { and } 10^{-5} \mathrm{M}\end{array}$ & {$[24,71]$} \\
\hline
\end{tabular}


Table 1. Cont.

\begin{tabular}{|c|c|c|}
\hline Source(s) and Compound(s) & Biological/pharmacological Activities & References \\
\hline $4^{\prime}$,2-dihydroxy-4,6-dimethoxydihydrochalcone (98) & $\begin{array}{l}\text { Stimulation of the MCF-7 cell proliferation in a concentration dependent manner between } 10^{-8} \\
\text { and } 10^{-5} \mathrm{M}\end{array}$ & {$[71]$} \\
\hline 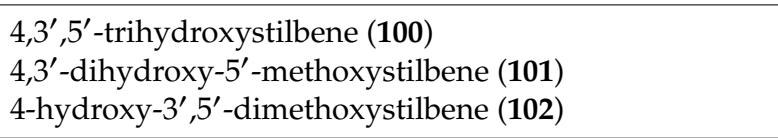 & $\begin{array}{l}\text { Inhibitory activities of the enzymes COX-1 and COX-2: } 100\left(\mathrm{IC}_{50}=2.61 \text { and } 2.16 \mu \mathrm{M} \text {, }\right. \\
\text { respectively); } 101\left(\mathrm{IC}_{50}=4.92 \text { and } 2.21 \mu \mathrm{M} \text {, respectively); } 102\left(\mathrm{IC}_{50}=4.84 \text { and } 1.29 \mu \mathrm{M} \text {, }\right.\right. \\
\text { respectively) }\end{array}$ & {$[72]$} \\
\hline 5,7,4'-trihydroxyhomoisoflavanone (4) & Binding affinity for the bovine uterine estrogen receptor $\left(\mathrm{IC}_{50}=375 \mathrm{nM}\right)$ & [71] \\
\hline \multicolumn{3}{|l|}{ Dracaena usambarensis } \\
\hline $\begin{array}{l}\text { (3S)-3,4',5,6-tetrahydroxy-7-methoxyhomoisoflavanone } \\
\text { (104) }\end{array}$ & Moderate cytotoxicity against drug sensitive human lymphoblastic leukemia CCRF-CEM cells & [76] \\
\hline \multicolumn{3}{|l|}{ Sansevieria cylindrica } \\
\hline (+)-trifasciatine C (114) & Moderate cytotoxicity against MCF7 cells $\left(\mathrm{IC}_{50}=34.1 \mu \mathrm{g} / \mathrm{mL}\right)$ & [80] \\
\hline (+)-trifasciatine B (116) & Weak DPPH radical scavenging activity $\left(\mathrm{IC}_{50}=35.2 \mu \mathrm{g} / \mathrm{mL}\right)$ & [81] \\
\hline lanceolatin B (121) & High cancer chemopreventive potential, anti-neuroinflammatory and analgesic properties & {$[84,85]$} \\
\hline
\end{tabular}




\section{Conclusions}

The field of natural product chemistry has greatly contributed to the progress of pharmacology and medicine. The wide range of bioactive compounds isolated from different plants still motivate many research groups worldwide to find new bioactive constituents and to determine their structures and biological activities. In this review we have reported the most characteristic structures and bioactivities of flavonoids and stilbenes isolated from Dracaena and Sansevieria species. These plants have revealed to be rich sources of compounds having unprecedented structures and exhibiting a wide range of biological and pharmacological properties. More attention has been devoted to Dracaena than Sansevieria flavonoids, possibly due to the very well-known effects of the red resin dragon's blood, that is collected from some Dracaena species and is widely used in several Asian traditional medicines. Indeed, the number and diversity of flavonoids isolated from Dracaena dragon's blood are impressive, encompassing a great number of chemical families. In addition, the potential therapeutic effects of the drug and individual constituents on different diseases are attractive, such as the remarkable activities on cardiovascular, inflammatory, and cerebrovascular diseases. However, more in vitro and in vivo scientific experiments must be programmed and carried out before the effective material may be qualified as a suitable candidate for clinical trials.

Compared to the phytochemical investigations conducted on Dracaena spp., those concerning Sansevieria species are less numerous and isolated flavonoids are chemically less diverse. However, the structural similarities of flavonoids isolated from Sansevieria and Dracaena plants seem to justify, on a chemotaxonomic basis, the recent inclusion of Sansevieria species inside the genus Dracaena.

Author Contributions: Conceptualization-writing, Z.M.T.; writing-original draft preparation, K.K.M. and H.T.A.; review supervision-editing, G.V.; literature retrieval, C.A. All authors have read and agreed to the published version of the manuscript.

Funding: This research received no external funding.

Conflicts of Interest: The authors declare no conflict of interest.

\section{References}

1. Angiosperm Phylogeny Group. An update of the Angiosperm Phylogeny Group classification for the orders and families of flowering plants: APG IV. Bot. J. Linn. Soc. 2016, 181, 1-20. [CrossRef]

2. Lu, P.-L.; Morden, C.W. Phylogenetic relationships among dracaenoid genera (Asparagaceae: Nolinoideae) inferred from chloroplast DNAloci. Syst. Bot. 2014, 39, 90-104. [CrossRef]

3. Takawira-Nyenya, R.; Mucina, L.; Cardinal-Mcteague, W.M.; Thiele, K.R. Sansevieria (Asparagaceae, nolinoideae) is a herbaceous clade within Dracaena: Inference from non-coding plastid and nuclear DNA sequence data. Phytotaxa 2018, 376, 254-276. [CrossRef]

4. Maděra, P.; Forrest, A.; Hanáček, P.; Vahalík, P.; Gebauer, R.; Plichta, R.; Jupa, R.; Van Rensburg, J.J.; Morris, M.; Nadezhdina, N.; et al. What we know and what we do not know about dragon trees? Forests 2020, 11, 236. [CrossRef]

5. WFO. World Flora Online. Published on the Internet. 2020. Available online: http://www.worldfloraonline. org (accessed on 26 April 2020).

6. Zhang, Z.; Zhang, Y.; Song, M.; Guan, Y.; Ma, X. Species identification of Dracaena using the complete chloroplast genome as a super-barcode. Front. Pharmacol. 2020, 11, 51. [CrossRef]

7. Wu, C.; Cai, X.-Q.; Chang, Y.; Chen, C.-H.; Ho, T.-J.; Lai, S.-C.; Chen, H.-P. Rapid identification of dragon blood samples from Daemonorops draco, Dracaena cinnabari and Dracaena cochinchinensis by MALDI-TOF mass spectrometry. Phytochem. Anal. 2019, 30, 720-726. [CrossRef]

8. Sun, J.; Liu, J.-N.; Fan, B.; Chen, X.-N.; Pang, D.-R.; Zheng, J.; Zhang, Q.; Zhao, Y.-F.; Xiao, W.; Tu, P.-F.; et al. Phenolic constituents, pharmacological activities, quality control, and metabolism od Dracaena species: A review. J. Ethnopharmacol. 2019, 244, 439-444. [CrossRef]

9. Gupta, D.; Bleakley, B.; Gupta, R.K. Dragon's blood: Botany, chemistry and therapeutic uses. J. Ethnopharmacol. 2008, 115, 361-380. [CrossRef]

10. Cai, X.T.; Xu, Z.F. A study on the resource of Chinese dragon's blood. Yunnan Zhi Wu Yan Jiu 1979, 1, 1-10. 
11. Fan, J.-Y.; Yi, T.; Sze-To, C.-M.; Zhu, L.; Peng, W.-L.; Zhang, Y.-Z.; Zhao, Z.-Z.; Chen, H.-B. A systematic review of the botanical, phytochemical and pharmacological profile of Dracaena cochinchinensis, a plant source of the ethnomedicine "dragon's blood". Molecules 2014, 19, 10650-10669. [CrossRef] [PubMed]

12. Machala, M.; Kubínová, R.; Hořavová, P.; Suchý, V. Chemoprotective potentials of homoisoflavonoids and chalcones of Dracaena cinnabari: Modulations of drug-metabolizing enzymes and antioxidant activity. Phytother. Res. 2001, 15, 114-118. [CrossRef] [PubMed]

13. Silva, B.M.; Santos, R.P.; Mendes, L.S.; de Pinho, P.G.; Valentão, P.; Andrade, P.B.; Pereira, J.A.; Carvalho, M. Dracaena draco L. fruit: Phytochemical and antioxidant activity assessment. Food. Res. Int. 2011, 44, 2182-2189. [CrossRef]

14. Mbugua, P.K.; Moore, D.M. Taxonomic studies of the genus Sansevieria (Dracaenaceae). In The Biodiversity of African Plants; Van der Maesen, L.J.G., Van der Burgt, M., Van Medenbach de Rooy, J.M., Eds.; Springer: Dordrecht, The Netherlands, 1996; pp. 489-492.

15. Takawira, R.; Nordal, I. The genus of Sansevieria (family Dracaenaceae) in Zimbabwe. Acta Hortic. 2002, 572, 189-198. [CrossRef]

16. Menale, B.; De Luca, P.; Del Guacchio, E. A plea to restore Petagna's authorship for the genus Sansevieria, nom. cons. (Liliaceae). Taxon 2013, 62, 387-390. [CrossRef]

17. Andhare, R.N.; Raut, M.K.; Naik, S.R. Evaluation of antiallergic and anti-anaphylactic activity of ethanolic extract of Sanseveiria trifasciata leaves (EEST) in rodents. J. Ethnopharmacol. 2012, 142, 627-633. [CrossRef] [PubMed]

18. Bero, J.; Ganfon, H.; Jonville, M.-C.; Frédérich, M.; Gbaguidi, F.; DeMol, P.; Moudachirou, M.; Quetin-Leclercq, J. In vitro antiplasmodial activity of plants used in Benin in traditional medicine to treat malaria. J. Ethnopharmacol. 2009, 122, 439-444. [CrossRef]

19. Kpodar, M.S.; Karou, S.D.; Katawa, G.; Anani, K.; Gbekley, H.E.; Adjrah, Y.; Tchacondo, T.; Batawila, K.; Simpore, J. An ethnobotanical study of plants used to treat liver diseases in the maritime region of Togo. J. Ethnopharmacol. 2016, 181, 263-273. [CrossRef]

20. Giovannini, P.; Howes, M.-J.R. Medicinal plants used to treat snakebite in Central America: Review and assessment of scientific evidence. J. Ethnopharmacol. 2017, 199, 240-256. [CrossRef]

21. Lekawatana, S.; Suwannamek, B. Ornamental plants in Thailand. Acta Hortic. 2017, 1167, 11-16. [CrossRef]

22. Saxena, P.; Ghosh, C. Ornamental plants as sinks and bioindicators. Environ. Technol. 2013, 34, 3059-3067. [CrossRef]

23. Zhao, T.; Nong, X.-H.; Zhang, B.; Tang, M.-M.; Huang, D.-Y.; Wang, J.-L.; Xiao, J.-L.; Chen, G.-Y. New flavones from the stems of Dracaena angustifolia. Phytochem. Lett. 2020, 36, 115-119. [CrossRef]

24. Luo, Y.; Wang, H.; Zhao, Y.-X.; Zeng, Y.-B.; Shen, H.-Y.; Dai, H.-F.; Mei, W.-L. Cytotoxic and antibacterial flavonoids from dragon's blood of Dracaena cambodiana. Planta Med. 2011, 77, 2053-2056. [CrossRef] [PubMed]

25. Chen, H.-Q.; Zuo, W.-J.; Wang, H.; Shen, H.-Y.; Luo, Y.; Dai, H.-F.; Mei, W.-L. Two new antimicrobial flavanes from dragon's blood of Dracaena cambodiana. J. Asian Nat. Prod. Res. 2012, 14, 436-440. [CrossRef] [PubMed]

26. Mei, W.-L.; Luo, Y.; Wang, H.; Shen, H.-Y.; Zeng, Y.-B.; Dai, H.-F. Two new flavonoids from dragon's blood of Dracaena cambodiana. Bull. Korean Chem. Soc. 2013, 34, 1791-1794. [CrossRef]

27. Luo, Y.; Dai, H.-F.; Wang, H.; Mei, W.-L. Chemical constituents from dragon's blood of Dracaena cambodiana. Chin. J. Nat. Med. 2011, 9, 112-114. [CrossRef]

28. Dai, H.-F.; Wang, H.; Liu, J.; Wu, J.; Mei, W.-L. Two new biflavonoids from the stem of Dracaena cambodiana. Chem. Nat. Compd. 2012, 48, 376-378. [CrossRef]

29. Liu, J.; Dai, H.-F.; Wu, J.; Zeng, Y.-B.; Mei, W.-L. Flavanes from Dracaena cambodiana. Z. Naturforsch. B. 2008, 63, 1407-1410. [CrossRef]

30. Liu, J.; Mei, W.-L.; Wu, J.; Zhao, Y.-X.; Peng, M.; Dai, H.-F. A new cytotoxic homoisoflavonoid from Dracaena cambodiana. J. Asian Nat. Prod. Res. 2009, 11, 192-195. [CrossRef]

31. Wang, H.; Jiang, H.-M.; Li, F.-X.; Chen, H.-Q.; Liu, W.-C.; Ren, S.-Z.; Mei, W.-L.; Dai, H.-F. Flavonoids from artificially induced dragon's blood of Dracaena cambodiana. Fitoterapia 2017, 121, 1-5. [CrossRef]

32. Wang, H.; Liu, J.; Wu, J.; Mei, W.-L.; Dai, H.-F. Flavonoids from Dracaena cambodiana. Chem. Nat. Compd. 2011, 47, 624-626. [CrossRef]

33. Luo, Y.; Wang, H.; Xu, X.; Mei, W.; Dai, H. Antioxidant phenolic compounds of Dracaena cambodiana. Molecules 2010, 15, 8904-8914. [CrossRef] [PubMed] 
34. Li, F.-X.; Wang, H.; Gai, C.-J.; Chen, H.-Q.; Li, W.; Mei, W.-L.; Dai, H.-F. Three new flavanoids from artificially induced dragon's blood of Dracaena cambodiana. J. Asian Nat. Prod. Res. 2017, 20, 55-61. [CrossRef] [PubMed]

35. Masaoud, M.; Ripperger, H.; Porzel, A.; Adam, G. Flavonoids of dragon's blood from Dracaena cinnabari. Phytochemistry 1995, 38, 745-749. [CrossRef]

36. Gupta, D.; Verma, N.; Das, H.R.; Gupta, R.K. Evaluation of anti-inflammatory activity of Dracaena cinnabari Balf. f. resin. Indian J. Nat. Prod. Resour. 2014, 5, 215-222.

37. Helal, I.E.; Elsbaey, M.; Zaghloul, A.M.; Mansour, E.-S.S. A unique C-linked chalcone-dihydrochalcone dimer from Dracaena cinnabari resin. Nat. Prod. Res. 2019, 1-6. [CrossRef]

38. Himmelreich, U.; Masaoud, M.; Adam, G.; Ripperger, H. Damalachawin, a triflavonoid of a new structural type from dragon's blood of Dracaena cinnabari. Phytochemistry 1995, 39, 949-951. [CrossRef]

39. Masaoud, M.; Ripperger, H.; Himmelreich, U.; Adam, G. Cinnabarone, a biflavonoid from dragon's blood of Dracaena cinnabari. Phytochemistry 1995, 38, 751-753. [CrossRef]

40. Masaoud, M.; Himmelreich, U.; Ripperger, H.; Adam, G.J.P.M. New biflavonoids from dragon's blood of Dracaena cinnabari. Planta Med. 1995, 61, 341-344. [CrossRef]

41. Veselá, D.; Marek, R.; Ubik, K.; Lunerová, K.; Sklenář, V.R.; Suchý, V. Dracophane, a metacyclophane derivative from the resin of Dracaena cinnabari Balf. Phytochemistry 2002, 61, 967-970. [CrossRef]

42. Tang, Y.; Su, G.; Li, N.; Li, W.; Chen, G.; Chen, R.; Zhou, D.; Hou, Y. Preventive agents for neurodegenerative diseases from resin of Dracaena cochinchinensis attenuate LPS-induced microglia over-activation. J. Nat. Med. 2019, 73, 318-330. [CrossRef]

43. Li, N.; Ma, Z.; Li, M.; Xing, Y.; Hou, Y. Natural potential therapeutic agents of neurodegenerative diseases from the traditional herbal medicine Chinese dragon's blood. J. Ethnopharmacol. 2014, 152, 508-521. [CrossRef] [PubMed]

44. Hao, Q.; Saito, Y.; Matsuo, Y.; Li, H.-Z.; Tanaka, T. Chalcane-stilbene conjugates and oligomeric flavonoids from Chinese dragon's blood produced from Dracaena cochinchinensis. Phytochemistry 2015, 119, 76-82. [CrossRef] [PubMed]

45. He, L.; Wang, Z.-H.; Liu, X.-H.; Fang, D.-C.; Li, H.-M. Cochinchin from Dracaena cochinchinensis. Chin. J. Chem. 2004, 22, 867-869. [CrossRef]

46. Zheng, Q.-A.; Li, H.-Z.; Zhang, Y.-J.; Yang, C.-R. Flavonoids from the resin of Dracaena cochinchinensis. Helv. Chim. Acta 2004, 87, 1167-1171. [CrossRef]

47. Zhu, Y.; Zhang, P.; Yu, H.; Li, J.; Wang, M.-W.; Zhao, W. Anti-helicobacter pylori and thrombin inhibitory components from Chinese dragon's blood, Dracaena cochinchinensis. J. Nat. Prod. 2007, 70, 1570-1577. [CrossRef]

48. Su, X.-Q.; Song, Y.-L.; Zhang, J.; Huo, H.-X.; Huang, Z.; Zheng, J.; Zhang, Q.; Zhao, Y.-F.; Xiao, W.; Li, J.; et al. Dihydrochalcones and homoisoflavanes from the red resin of Dracaena cochinchinensis (Chinese dragon's blood). Fitoterapia 2014, 99, 64-71. [CrossRef]

49. Xu, X.; Cheng, K.; Cheng, W.; Zhou, T.; Jiang, M.; Xu, J. Isolation and characterization of homoisoflavonoids from Dracaena cochinchinensis and their osteogenic activities in mouse mesenchymal stem cells. J. Pharm. Biomed. Anal. 2016, 129, 466-472. [CrossRef]

50. Yong, K.-L.; Lv, J.-C.; Zhang, T.-B.; Xu, L.-R.; Chen, X. A new dihydrochalcone from dragon's blood, red resin of Dracaena cochinchinensis. Nat. Prod. Res. 2008, 22, 1624-1626. [CrossRef]

51. Lu, W.J.; Wang, X.F.; Chen, J.F.; Lv, Y.; Wu, N.; Kang, W.J.; Zheng, Q.T. Studies on the chemical constituents of chloroform extract of Dracaena cochinchinensis. Acta Pharm. Sin. 1998, 33, 755-758. [CrossRef]

52. Pang, D.-R.; Pan, B.; Sun, J.; Sun, H.; Yao, H.-N.; Song, Y.-L.; Zhao, Y.-F.; Tu, P.-F.; Huang, W.-Z.; Zheng, J.; et al. Homoisoflavonoid derivatives from the red resin of Dracaena cochinchinensis. Fitoterapia 2018, 131, 105-111. [CrossRef]

53. Lang, G.-Z.; Li, C.-J.; Gaohu, T.-Y.; Li, C.; Ma, J.; Yang, J.-Z.; Zhou, T.-T.; Yuan, Y.-H.; Ye, F.; Wei, J.-H.; et al. Bioactive flavonoid dimers from Chinese dragon's blood, the red resin of Dracaena cochinchinensis. Bioorg. Chem. 2020, 97, 103659. [CrossRef] [PubMed]

54. Zheng, Q.; Xu, M.; Yang, C.; Wang, D.; Li, H.; Zhu, H.; Zhang, Y. A new red pigment from Chinese dragon's blood, the red resin of Dracaena cochinchinensis. Bull. Korean Chem. Soc. 2012, 33, 4204-4206. [CrossRef]

55. Zheng, Q.-A.; Xu, M.; Yang, C.-R.; Wang, D.; Li, H.-Z.; Zhu, H.-T.; Zhang, Y.-J. Flavonoid oligomers from Chinese dragon's blood, the red resin of Dracaena cochinchinensis. Nat. Prod. Bioprospect. 2012, 2, 111-116. [CrossRef] 
56. Pang, D.-R.; Su, X.-Q.; Zhu, Z.-X.; Sun, J.; Li, Y.-T.; Song, Y.-L.; Zhao, Y.-F.; Tu, P.-F.; Zheng, J.; Li, J. Flavonoid dimers from the total phenolic extract of Chinese dragon's blood, the red resin of Dracaena cochinchinensis. Fitoterapia 2016, 115, 135-141. [CrossRef] [PubMed]

57. Guan, J.; Guo, S.-X. Three new biflavonoids from chinese dragon's blood, Dracaena cochinchinensis. Nat. Prod. Commun. 2012, 7, 591-594. [CrossRef] [PubMed]

58. Niu, S.; Liu, T.; Deng, Y.; Wang, W.; Zhang, Y.; Hong, W.; Zhang, D.; Hua, J.; Luo, S. Production and evaluation of antifungal stilbenoids in Dracaena cochinchinensis elicited by fungal inoculation. Ind. Crops Prod. 2020, 145, 112148. [CrossRef]

59. Hu, L.; Wang, F.-F.; Wang, X.-H.; Yang, Q.-S.; Xiong, Y.; Liu, W.-X. Phytoconstituents from the leaves of Dracaena cochinchinensis (Lour.) S. C. Chen. Biochem. Syst. Ecol. 2015, 63, 1-5. [CrossRef]

60. Zheng, Q.A.; Zhang, Y.J.; Yang, C.R. A new meta-homoisoflavane from the fresh stems of Dracaena cochinchinensis. J. Asian Nat. Prod. Res. 2006, 8, 571-577. [CrossRef]

61. Camarda, L.; Merlini, L.; Nasini, G. Dragon's blood from Dracaena draco, structure of novel homoisoflavanoids. Heterocycles 1983, 20, 39-43. [CrossRef]

62. González, A.G.; León, F.; Sánchez-Pinto, L.; Padrón, J.I.; Bermejo, J. Phenolic compounds of dragon's blood from Dracaena draco. J. Nat. Prod. 2000, 63, 1297-1299. [CrossRef]

63. González, A.G.; León, F.; Hernández, J.C.; Padrón, J.I.; Sánchez-Pinto, L.; Barrera, J.B. Flavans of dragon's blood from Dracaena draco and Dracaena tamaranae. Biochem. Syst. Ecol. 2004, 32, 179-184. [CrossRef]

64. Di Stefano, V.; Pitonzo, R.; Schillaci, D. Phytochemical and anti-staphylococcal biofilm assessment of Dracaena draco L. spp. Draco Resin. Pharmacogn. Mag. 2014, 10, 434-440. [CrossRef] [PubMed]

65. Hernández, J.C.; León, F.; Estévez, F.; Quintana, J.; Bermejo, J. A homo-isoflavonoid and a cytotoxic saponin from Dracaena draco. Chem. Biodivers. 2006, 3, 62-68. [CrossRef] [PubMed]

66. Hernández, J.C.; León, F.; Quintana, J.; Estévez, F.; Bermejo, J. Icogenin, a new cytotoxic steroidal saponin isolated from Dracaena draco. Bioorg. Med. Chem. 2004, 12, 4423-4429. [CrossRef]

67. González, A.G.; Hernández, J.C.; León, F.; Padrón, J.I.; Estévez, F.; Quintana, J.; Bermejo, J. Steroidal saponins from the bark of Dracaena draco and their cytotoxic activities. J. Nat. Prod. 2003, 66, 793-798. [CrossRef]

68. Roskov, Y.; Ower, G.; Orrell, T.; Nicolson, D.; Bailly, N.; Kirk, P.M.; Bourgoin, T.; DeWalt, R.E.; Decock, W.; Nieukerken, E.; et al. Species 2000 E ITIS Catalogue of Life; Naturalis: Leiden, The Netherlands, 2020; ISSN 2405-8858. Available online: www.catalogueoflife.org/col (accessed on 24 February 2020).

69. Meksuriyen, D.; Cordell, G.A. Retrodihydrochalcones from Dracaena loureiri. J. Nat. Prod. 1988, 51, 1129-1135. [CrossRef]

70. Sun, X.; Wen, K.; Xu, Z.; He, Z.; Wu, B.; Yang, X.; Wang, X. Effect of loureirin B on Crohn's disease rat model induced by TNBS via IL-6/STAT3/NF-kB signaling pathway. Chin. Med. 2020, 15, 2. [CrossRef]

71. Ichikawa, K.; Kitaoka, M.; Taki, M.; Takaishi, S.; Boriboon, M.; Akiyama, T. Retrodihydrochalcones and homoisoflavones isolated from Thai medicinal plant Dracaena loureiri and their estrogen agonist activity. Planta Med. 1997, 63, 540-543. [CrossRef]

72. Likhitwitayawuid, K.; Sawasdee, K.; Kirtikara, K. Flavonoids and stilbenoids with COX-1 and COX-2 inhibitory activity from Dracaena loureiri. Planta Med. 2002, 68, 841-843. [CrossRef]

73. Cheng, S.; Rong, Y.; Ma, M.; Lin, X.; Liu, X.; Li, C.; Yang, X.; Chen, S. Modulation on tetrodotoxin-resistant sodium current of loureirin $\mathrm{B}$ in rat dorsal root ganglion neurons via cyclic AMP-dependent protein kinase A. J. Cell. Biochem. 2020, 121, 1790-1800. [CrossRef]

74. Sha, Y.; Zhang, Y.; Cao, J.; Qian, K.; Niu, B.; Chen, Q. Loureirin B promotes insulin secretion through inhibition of $\mathrm{K}_{\mathrm{ATP}}$ channel and influx of intracellular calcium. J. Cell. Biochem. 2018, 119, 2012-2021. [CrossRef]

75. Meksuriyen, D.; Cordell, G.A.; Ruangrungsi, N.; Tantivatana, P. Traditional medicinal plants of Thailand, IX. 10-Hydroxy-11-methoxydracaenone and 7,10-dihydroxy-11-methoxydracaenone from Dracaena loureiri. J. Nat. Prod. 1987, 50, 1118-1125. [CrossRef]

76. Nchiozem-Ngnitedem, V.-A.; Omosa, L.K.; Derese, S.; Tane, P.; Heydenreich, M.; Spiteller, M.; Seo, E.-J.; Efferth, T. Two new flavonoids from Dracaena usambarensis Engl. Phytochem. Lett. 2020, 36, 80-85. [CrossRef]

77. Moharram, F.A.; EI-Shenawy, S.M. Antinociceptive and anti-inflammatory steroidal saponins from Dracaena ombet. Planta Med. 2007, 73, 1101-1106. [CrossRef]

78. Yokosuka, A.; Sekiguchi, A.; Mimaki, Y. Chemical constituents of the leaves of Dracaena thalioides. Nat. Prod. Commun. 2013, 8, 315-318. [CrossRef] [PubMed] 
79. Melo, M.J.; Sousa, M.; Parola, A.J.; de Melo, J.S.S.; Catarino, F.; Marçalo, J.; Pina, F. Identification of 7,4'-dihydroxy-5-methoxyflavylium in "dragon's blood": To be or not to be an anthocyanin. Chem. Eur. J. 2007, 13, 1417-1422. [CrossRef]

80. Raslan, M.A.; Melek, F.R.; Said, A.A.; Elshamy, A.I.; Umeyama, A.; Mounier, M.M. New cytotoxic dihydrochalcone and steroidal saponins from the aerial parts of Sansevieria cylindrica Bojer ex Hook. Phytochem. Lett. 2017, 22, 39-43. [CrossRef]

81. Said, A.; Aboutabl, E.A.; Melek, F.R.; Abdel Jaleel, G.A.R.; Raslan, M. Steroidal saponins and homoisoflavanone from the aerial parts of Sansevieria cylindrica Bojer ex Hook. Phytochem. Lett. 2015, 12, 113-118. [CrossRef]

82. Aye, M.M.; Aung, H.T.; Thu, Z.M.; Sein, M.M.; Takaya, Y.; Komori, Y.; Clericuzio, M.; Vidari, G. Constituents of the rhizomes of Sansevieria cylindrica. Nat. Prod. Commun. 2018, 13, 1129-1132. [CrossRef]

83. Aung, H.T.; Aye, M.M.; Thu, Z.M.; Komori, Y.; Sein, M.M.; Vidari, G.; Takaya, Y. Bioactive constituents from the rhizomes of Sansevieria cylindrica. Rec. Nat. Prod. 2020, 14, 269-275. [CrossRef]

84. Sharma, R.; Williamd, I.S.; Gatchie, L.; Sonawane, V.R.; Chaudhuri, B.; Bharate, S.B. Furanoflavones pongapin and lanceolatin B block the cell cycle and induce senescence in CYP1A1-overexpressing breast cancer cells. Biorg. Med. Chem. 2018, 26, 6076-6086. [CrossRef]

85. Xuo, X.; Zhang, L.; Gao, L.; Guo, Y.; Zhang, L.; Li, L.; Si, J.; Cao, L. Antiinflammatory and analgesic activities of ethanol extract and isolated compounds from Millettia pulchra. Biol. Pharm. Bull. 2015, 38, 1328-1336.

86. Roy, J.; Aktar, F.; Haq, M.R.; Begum, B.; Hasan, C.M. A rare homoisoflavonoid cambodianol from Sansevieria roxburghiana. Asian J. Chem. 2013, 25, 5113-5114. [CrossRef]

87. Tchegnitegni, B.T.; Teponno, R.B.; Tanaka, C.; Gabriel, A.F.; Tapondjou, L.A.; Miyamoto, T. Sappanin-type homoisoflavonoids from Sansevieria trifasciata Prain. Phytochem. Lett. 2015, 12, 262-266. [CrossRef]

88. Tchegnitegni, B.T.; Teponno, R.B.; Jenett-Siems, K.; Melzig, M.F.; Miyamoto, T.; Tapondjou, L.A. A dihydrochalcone derivative and further steroidal saponins from Sansevieria trifasciata Prain. Z. Naturforsch. C J. Biosci. 2017, 72, 477-482. [CrossRef] [PubMed]

89. Castelli, M.V.; López, S.N. Homoisoflavonoids: Occurrence, biosynthesis, and biological activity. In Studies in Natural Products Chemistry, 1st ed.; Elsevier: Amsterdam, The Netherlands, 2017; Volume 54, pp. 315-354.

(C) 2020 by the authors. Licensee MDPI, Basel, Switzerland. This article is an open access article distributed under the terms and conditions of the Creative Commons Attribution (CC BY) license (http://creativecommons.org/licenses/by/4.0/). 